\title{
Fixing the broken clock in adrenal disorders focus on glucocorticoids and chronotherapy
}

\author{
Marianna Minnetti ${ }^{1}$, Valeria Hasenmajer ${ }^{1}$, Riccardo Pofi ${ }^{1}$, Mary Anna Venneri ${ }^{1}$, Krystallenia I Alexandraki ${ }^{2}$ and \\ Andrea M Isidori ${ }^{D} 1$
}

\begin{abstract}
1Department of Experimental Medicine, Sapienza University of Rome, Rome, Italy
2Endocrine Unit, 1st Department of Propaedeutic Medicine, Laiko University Hospital, Medical School, National and Kapodistrian University of Athens, Athens, Greece
\end{abstract}

Correspondence should be addressed to A M Isidori: andrea.isidori@uniroma1.it

§Invited Review - This work was presented in part during a Symposium at the 2019 European Conference of Endocrinology - Lyon.

\begin{abstract}
The circadian rhythm derives from the integration of many signals that shape the expression of clock-related genes in a 24-h cycle. Biological tasks, including cell proliferation, differentiation, energy storage, and immune regulation, are preferentially confined to specific periods. A gating system, supervised by the central and peripheral clocks, coordinates the endogenous and exogenous signals and prepares for transition to activities confined to periods of light or darkness. The fluctuations of cortisol and its receptor are crucial in modulating these signals. Glucocorticoids and the autonomous nervous system act as a bridge between the suprachiasmatic master clock and almost all peripheral clocks. Additional peripheral synchronizing mechanisms including metabolic fluxes and cytokines stabilize the network. The pacemaker is amplified by peaks and troughs in cortisol and their response to food, activity, and inflammation. However, when the glucocorticoid exposure pattern becomes chronically flattened at high- (as in Cushing's syndrome) or low (as in adrenal insufficiency) levels, the system fails. While endocrinologists are well aware of cortisol rhythm, too little attention has been given to interventions aimed at restoring physiological cortisol fluctuations in adrenal disorders. However, acting on glucocorticoid levels may not be the only way to restore clock-related activities. First, a counterregulatory mechanism on the glucocorticoid receptor itself controls signal transduction, and second, melatonin and/or metabolically active drugs and nutrients could also be used to modulate the clock. All these aspects are described herein, providing some insights into the emerging role of chronopharmacology, focusing on glucocorticoid excess and deficiency disorders.
\end{abstract}

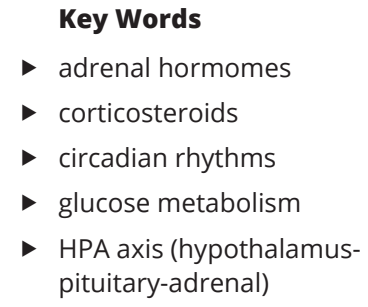

Journal of Endocrinology (2020) 246, R1-R20

\section{Introduction}

Human physiology and behavior are adapted to daily environmental cycles by means of endogenous circadian clocks. In mammals, the molecular mechanism of these clocks is generated by a transcriptional autoregulatory feedback loop. The 'core' clock genes include the master genes CLOCK and BMAL1 (also named ARNTL). Their expression, however, also activates some other proteins that serve as counterbalances and gradually build up in cells over a 12-h period, progressively inhibiting the activity of the master genes. This itself progressively 
reduces the activation of the counterbalances, which then slowly degrade over the next $12 \mathrm{~h}$, causing CLOCK and BMAL1 to bounce back.

However, the mechanism is much more complicated. Clock genes interact with many different signals to produce an integrated output over the 24-h cycle, entraining other cycling activity such as cell division and metabolism, in preparation for the different tasks confined to periods of light or darkness. During the transition hours between activity and rest periods, gene expression increases in a non-linear manner, with a gating system enhancing or softening signal transduction to avoid interferences of misaligned cycles.

Peaks and troughs in adrenal hormones play a pivotal role in mitigating or enhancing the effects of clock genes on their own targets. The exact role of glucocorticoids in this context has yet to be fully elucidated. However, it is generally accepted that their circadian rhythm takes part in the entrainment of peripheral clocks by the master genes and, hence, with the light:darkness cycle. When the endogenous rhythm is disrupted by disease, such as in adrenal insufficiency, a non-physiologic timing of glucocorticoid administration may dysregulate circadian gene expression, as recently described (Venneri et al. 2018).
The use of pharmacological intervention on circadian genes has recently gained momentum, as a number of different studies have shown that synchronization of peripheral clocks is achieved not only through classic hierarchical vertical control from the hypothalamic master clock through the peripheral nervous system, which is already relatively independent of glucocorticoids, but also horizontally, through fluxes of nutrients absorbed after food consumption, metabolites produced by the liver and redirected to the peripheral tissues, gastrointestinal peptides, and cytokines derived from the immune system, bone, muscle, and adipose tissue (Fig. 1).

All these different inter-organ signals need to be integrated with the oscillation of the master clock to create a coordinated response. Glucocorticoids act mainly through this horizontal process, influencing the expression of the clock genes directly or the metabolic fluxes indirectly. However, the clock has developed a system of resistance to rapid desynchronization induced by glucocorticoid changes. This counterregulatory mechanism works to avoid rhythm disruption in the event that unexpected acute stress produces sudden changes in glucocorticoid levels. Recent data have also clearly demonstrated the circadian expression of clock

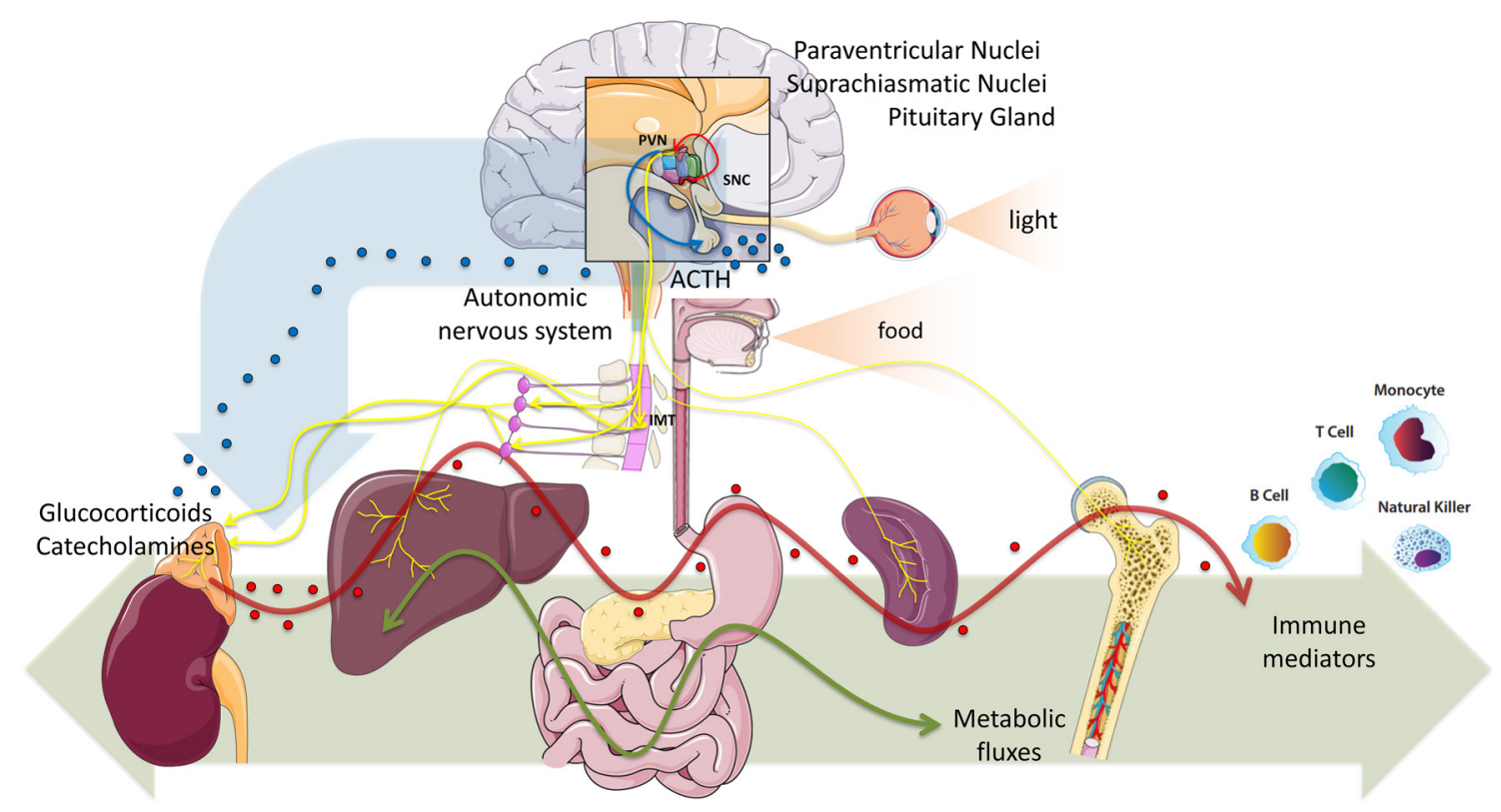

Figure 1

Schematic representation of (1.) the traditional vertical-hierarchical control system of the circadian rhythm (thick blue arrow), with control of the suprachiasmatic master clock nuclei (SCN) projecting to the paraventricular nuclei (PVN) and from there to the autonomic nervous system (ANS, yellow lines) and hypothalamic pituitary axis (HPA), blue lines and circles), the ANS provides a direct independent innervation of the adrenal gland by preganglionic fibers from the intermediolateral $(\mathrm{IML})$ column of the spinal cord and postganglionic fibers from the ganglia of the sympathetic chain and (2.) the bidirectional horizontal synchronization system (thick green arrow) comprising multiple signals from metabolic fluxes (from food intake and liver processing), cytokines (from immune cells), and peripheral modulation of glucocorticoid modulation (yellow line: ACTH; red line and circles: cortisol and catecholamines). 
genes in the adrenal gland, not only in cortisol-secreting adenomas, but also in aldosterone-producing adenomas and adrenocortical carcinomas (Angelousi et al. 2020).

All these aspects are described subsequently, providing some insights into the emerging role of chronopharmacology in hypothalamic-pituitary-adrenal (HPA) axis disorders. The concept of using glucocorticoids, glucocorticoid antagonists, or adrenal steroidogenesis inhibitors to reset the endogenous rhythm in disorders of the HPA axis is briefly presented. Finally, the use of drugs that target metabolism is also reviewed in this context, taking into account the growing awareness of metabolism as a further level of control of the endogenous clock.

\section{The vertical paradigm: hierarchical control of the HPA circadian rhythm}

The suprachiasmatic nucleus (SCN) of the hypothalamus receives information about light and darkness and is traditionally considered the 'master clock', coordinating the activities of the 'peripheral' clocks functioning in virtually all other organs (Fig. 1) (Dickmeis et al. 2013). The circadian clock is sustained by interlocked transcriptionaltranslational feedback loops comprised of the master genes CLOCK and BMAL1 (Nader et al. 2010, Partch et al. 2014, Moreira et al. 2018). They heterodimerize in the cytoplasm to form a complex (CLOCK-BMAL1) that binds to E-box elements in the nuclei, thereby enhancing the target genes, including two cryptochrome genes (CRY1 and CRY2) and the core-clock 'period' genes (PER1, PER2, and PER3). Over its $12 \mathrm{~h}$ of activity, the CLOCKBMAL1 complex induces the accumulation of CRY and PER proteins, which peak at the end of daylight. Since these inhibit CLOCK and BMAL1 transcription and hence suppress their own transcription, over the following $12 \mathrm{~h}$ of rest, PER is slowly degraded and CLOCK and BMAL1 surge back, resulting in a cycle of about $24 \mathrm{~h}$ (Brown et al. 2012).

In humans, glucocorticoids peak shortly before activity begins and decline during the remaining 24 $\mathrm{h}$, following a periodic non-linear oscillation (the oscillations do not have a sinusoidal shape). The circadian rhythmicity of cortisol is assumed to play a role in synchronizing the pace of the peripheral clocks with the central master clock (Nader et al. 2010, Dickmeis et al. 2013). This hypothesis was supported by evidence that dexamethasone injections transiently changed the phase of circadian gene expression in mouse liver, kidney, and heart, but not in the neurons of the SCN (Balsalobre et al. 2000). Such behavior was considered to support the presence of 'slave oscillators' that are synchronized by the 'master pacemaker' (via glucocorticoids), as they remain responsive to phase-resetting signals from the SCN, which in turn retain hierarchal independence.

Glucocorticoid fluctuations depend on the intrinsic expression of clock genes at each anatomical site of the HPA axis, classically organized in a hierarchical manner (Moreira et al. 2018). The SCN, through the activation of corticotropin-releasing hormone secretion from the paraventricular nuclei of the hypothalamus $(\mathrm{PVN})$, coordinates and controls the rhythmic release of adrenocorticotropic hormone (ACTH) from the anterior pituitary. ACTH, in turn, stimulates glucocorticoid production in the adrenal cortex (Dickmeis et al. 2013, Leliavski et al. 2015) (Fig. 1).

Obviously, the system is much more complicated than this. First, sympathetic innervation is required to maintain the cyclical activity of adrenal steroidogenesis (Ottenweller \& Meier 1982). Using viral retrograde transsynaptic tracer experiments, Buijs demonstrated a neural SCN-adrenal gland network that works in parallel with the HPA axis (Buijs et al. 2003). Sympathetic neurons of the SCN project to pre-autonomic neurons of the PVN, which in turn project to the preganglionic sympathetic neurons in the intermediolateral (IML) column of the spinal cord (Buijs et al. 2003). The adrenal gland receives both preganglionic and postganglionic sympathetic and parasympathetic innervation (Kesse et al. 1988). Most are fibers from the preganglionic sympathetic neurons in the IML, projecting to the medulla and, from there, as postganglionic fibers, to the cortex (Hinson 1990). However, a smaller number of projections, through the splanchnic nerves, are postganglionic sympathetic fibers from the ganglia of the sympathetic chain. Interestingly, vesicle-containing nerve endings have been observed in direct contact with cortical cells in the zona fasciculata of the human adrenal cortex (Dorovini-Zis \& Zis 1991). This network controls the circadian output of the adrenal gland in response to classical autonomic activation (e.g. light), but can also regulate sensitivity to ACTH and thus steroidogenesis (Ishida et al. 2005, Ulrich-Lai et al. 2006).

Second, glucocorticoids can modulate the expression and activity of clock-related genes (see subsequently) (Dickmeis et al. 2007). As a consequence, the self-sustained 12-h time-delayed transcriptional/posttranslational negative feedback loop, frequently analyzed using the single-component cosinor linear method, appears over-simplistic (Fig. 2, see Box 1 for cosinor-basedrhythmometry). 


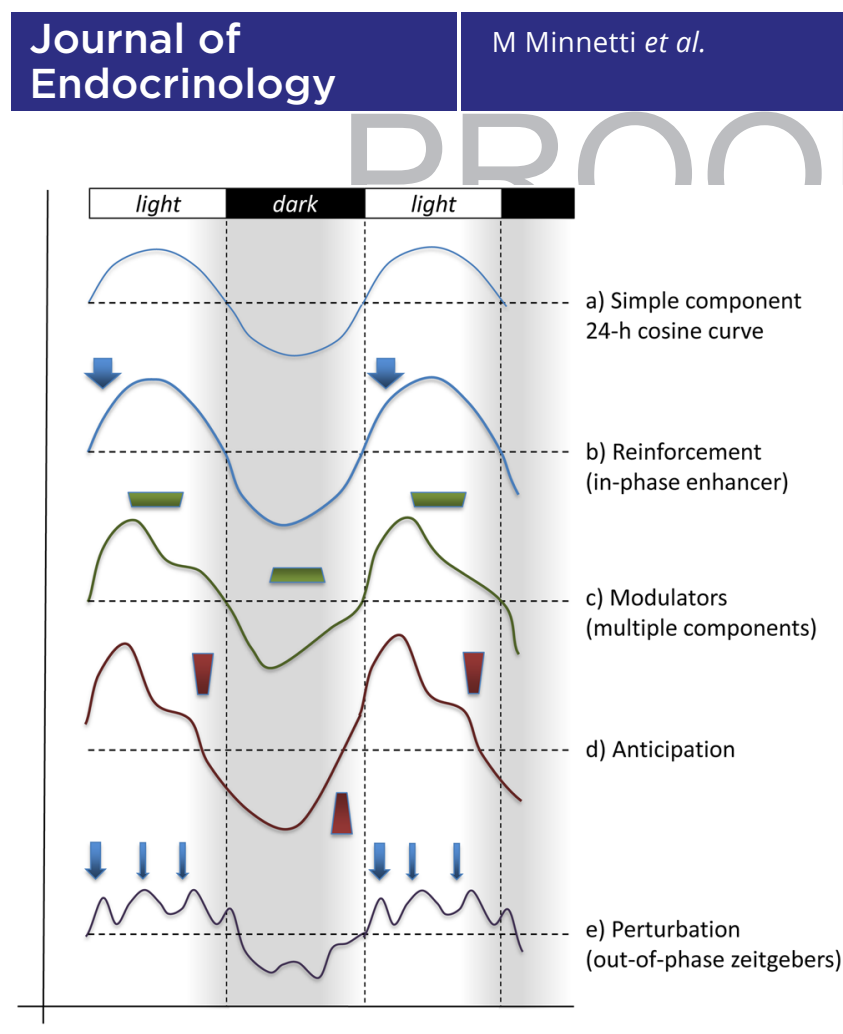

Third, pathological or physiological processes such as aging can interfere with this mechanism at either level, leading to circadian disruption. Aging dampens the photoperiodic adaptation, possibly by reducing the amplitude of signal transmission from SCN (Buijink et al. 2020), and alters the circadian rhythm of glucocorticoids and melatonin, contributing to the observed circadian derangement (Hood \& Amir 2017).

Gender can also influence circadian rhythms. Sex differences have been described at many levels of the circadian system, including in relation to SCN size and HPA axis vulnerability (Bailey \& Silver 2014). This leads to a different response and resilience to circadian 'challenges' such as stress: in fact, the adrenal clock seems to have a gating effect on stress response in a sexually dimorphic manner, with ACTH exerting a larger response from female adrenal glands, possibly due to the lower amplitude of the adrenal clock oscillation (Stagl et al. 2018). In summary, glucocorticoids and glucocorticoid receptor (GR) are important in re-shaping the cosinor-based rhytmometry,

Figure 2 but they are not the only agents involved (Fig. 2B and

Modelling of the single component 24-h cosinor (A) into a more complex model that better describes human physiology. Glucocorticoid fluctuations act as rhythm enhancers (B), while peripheral modulators (such as metabolic fluxes and cytokines) are responsible for the multiple components $(C)$ shaping the wave of the cosinor. An additional feature of human rhythmometry is the anticipation phenomenon, with a number of genes rushing the transition from active to resting phases (D). When all these components are disrupted by multiple abnormal out-of-phase signals, the overall rhythm is disrupted (E). C). In the next sections, the main endocrine-metabolic contributors to circadian rhythm are briefly reviewed, to provide the background for potential interventions in adrenal disorders.

\section{Box 1: Cosinor rhythmometry}

In 1822 Joseph Fourier developed the revolutionary intuition that each time series, regardless of its shape or regularity, can be described by a series of sine waves and cosines of various frequencies, also known as 'spectral analysis' (Fourier \& Freeman 1878). If the spectral analysis of a time series identifies a major spectral component of approximately a 24 -h period, the investigator can deduce that the study has a circadian rhythmicity. However, most biological studies, assuming that the period is known and of $24 \mathrm{~h}$, use the cosinor method. This method can be used for both non-equidistant data series (which cannot be easily done by the Fourier analysis) and serially independent data. A cosine curve with a given period is fitted to the data by least squares (single-component, Fig. 1A and B). This approach consists of minimizing the sum of squared deviations between the data and the fitted cosine curve. For complex biological rhythms, a multiple-component model helps obtain a better approximation of the signal's waveform when it deviates from sinusoidality. For instance, for blood pressure data, with its typical night drop, a 2-component model consisting of cosine curves with periods of 12 and $24 \mathrm{~h}$ is better than a single-component model, as can be easily assessed by the CIs for parameters of rhythmic components derived therefrom. In general, the advantage of cosinor methods is that biological rhythms can be considered as smooth rhythms with some added noise (Fig. 2C, D and E): a model consisting of superimposed cosine curves with known periods adapted from least squares to data (Refinetti et al. 2007). The single cosinor approach can be applied clinically by the population mean cosinor method, which provides an estimate of the population from the results of three or more individuals, assuming they were randomly sampled from the same population (Bingham et al. 1982). The procedure verifies the similarity of the individual results. Finally, linear regression of cosinor analysis works well if the period is known; when it is not, a non-linear approach can be used. Starting from an initial estimate for the period and applying subsequent iteration sequences aimed at minimizing the residual sum of squares, all parameters can be estimated (Cornelissen 2014). 


\section{Journal of \\ Endocrinology \\ pective: the importance of \\ The horizontal perspective: the importance of peripheral mediators}

The classic vertical hierarchic control mechanism is not sufficient to explain how the endogenous self-sustained clocks can remain in alignment despite the various perturbations introduced by cycling human activity or by disease. At least three additional pathways have recently emerged as independent players.

\section{Food and metabolism}

It is traditionally believed that eating late at night is related to weight gain and metabolic abnormalities. Furthermore, night and shift work have been considered as risk factors for metabolic and cardiovascular disorders (Biggi et al. 2008) and glucose metabolism abnormalities are described in circadian-related metabolic diseases (Stenvers et al. 2019). Late sleeping, short sleep duration $(<5 \mathrm{~h})$, and late dinnertime or consumption of additional calories later in the evening have been associated with obesity and diabetes (Colles et al. 2007, Baron et al. 2011, Hsieh et al. 2011). Glucocorticoid excess is associated with weight gain, altered food intake, and disrupted metabolism (Pivonello et al. 2016).

Eating is included in the non-photic time stimuli synchronizing the endogenous clock (Asher \& SassoneCorsi 2015) (Figs 1 and 2C). It interacts with brain structures projecting to the SCN through mediators such as orexin neurons and ghrelin (Mieda et al. 2004, LeSauter et al. 2009, Acosta-Galvan et al. 2011, Adamovich et al. 2017). In turn, leptin receptors in the SCN are time/ phase sensitive to leptin modulation (Guan et al. 1997). In mice, changing standard alternating light:darkness cycles to a light cycle where dim light replaced the darkness cycle resulted in increased food intake and, even when caloric intake and total motor activity were kept similar, led to excess weight gain (Fonken et al. 2010). Consistent with this, CLOCK-mutant mice exhibit an attenuated diurnal feeding rhythm and develop obesity and metabolic syndrome (Turek et al. 2005). Interestingly, the central SCN oscillator was apparently resistant to transient shifts in feeding time, while peripheral clocks, especially in the liver, were significantly affected (Damiola et al. 2000), uncoupling the peripheral oscillators from the central pacemaker. Changes in feeding time reset the phase of rhythmic gene expression in the liver first and only subsequently in other tissues, achieving full synchronization within a week. Studies on timerestricted feeding revealed that insulin-sensitive tissues such as the liver, adipose tissue and pancreas are pivotal in food anticipatory activity, with the liver playing the main role as the communication center (Fig. 2D) (Xie et al. 2019). Changes in feeding time are considered to affect body weight, particularly early vs later meals. An extensive study on more than 50,000 adults showed that those eating their largest meal at breakfast experienced a relatively large decrease in BMI compared with those eating their largest meal at lunch or dinner (Kahleova et al. 2017). In contrast, eating meals in the evening generally has the opposite effect and patients with night eating syndrome have a higher risk of developing obesity (Colles et al. 2007).

However, it is not only the timing but also the quality and quantity of ingredients that control the peripheral oscillators (Vollmers et al. 2009, Laermans et al. 2014, Pavlovski et al. 2018). While the central clock regulates food intake, energy expenditure, and insulin sensitivity, the peripheral tissue clocks are also believed to exert additional control over glucose uptake and secretion, insulin sensitivity, lipid biosynthesis, and catabolism. Eating increases blood glucose levels, which in turn can downregulate the expression of Per1 and Per2 in mice fibroblasts (Hirota et al. 2002) and indirectly regulate 5' AMP-activated protein kinase (AMPK), which controls the stability of clock component cryptochromes (Lamia et al. 2009). The increase in blood sugar and, consequently, insulin seems to lead to an increase in the endogenous synthesis of cholesterol (Jones et al. 1993).

Chrono-disruption with a high-fat diet alters the rhythm of both the central and peripheral clocks, attenuating feeding-fasting cycles and acting as a potent zeitgeber for peripheral clocks (Asher \& Sassone-Corsi 2015), for example, through the release of additional gastrointestinal peptides or bile (Turek et al. 2005, Fonken et al. 2010).

Conversely, clock gene expression can be induced by food ingestion in peripheral insulin-sensitive tissues (Oike et al. 2014), generating a horizontal feedback loop that is partially independent of the central clock. In obese mice, time-restricted feeding enhanced CREB (cAMP response element-binding protein), mTOR (mechanistic target of rapamycin) and AMPK pathway signaling and increased the oscillations of core and clock-controlled genes, and prevents hyperinsulinemia, hepatic steatosis, and inflammation. These results could be explained through the considerable crosstalk between the cell clock and the triggers induced by feeding (Fuse et al. 2012, Hatori et al. 2012, Sherman et al. 2012, Asher \& Sassone-Corsi 2015). Fasting, like the ketogenic diet, 
induces the phosphorylation of AMPK, which is involved in mitochondrial biogenesis and function. In contrast, a state of satiety stimulates mTOR, which promotes anabolism in response to energy availability in a complex crosstalk with the AMPK pathway (Fuse et al. 2012, Hatori et al. 2012, Sherman et al. 2012, Asher \& Sassone-Corsi 2015). Finally, mRNA transcript levels of melatonin receptors (MT1, MT2) were significantly higher in type 2 diabetic (T2D) patients than in a normal control group (Peschke et al. 2007). Thus, in principle, improving eating habits or using metabolically active drugs could be used to reprogram the clock (Table 1 ).

\section{The autonomous nervous system}

Peripheral clocks are directly controlled by autonomic nervous system (ANS) innervation, as shown in Fig. 1. The ANS can also transmit the SCN's pace to the peripheral clocks, influencing the metabolic processes described previously. Experimental models of sympathetic and parasympathetic denervation of the liver documented a circadian regulation of glucose production by ANS hypothalamic neurons, contributing to lipid metabolism and insulin sensitivity (Kalsbeek et al. 2010). Proof of this mechanism is offered by the preservation of the glucometabolic profile (along with normal clock gene oscillation in the liver) under an anti-circadian meal regimen (six meals a day), as opposed to its disruption after sympathetic denervation (Cailotto et al. 2005). Interestingly, the persistence of circadian expression of clock genes in hepatic sympathectomy suggests that redundant hormonal feedbacks are involved, including that of glucocorticoids.

The adrenergic system's ability to superimpose a circadian clock gene expression pattern in arrhythmic conditions has been demonstrated in SCN-lesioned mice, in which daily adrenalin injections or sympathetic stimulation produced a robust circadian rhythm of Per1 gene expression in the liver (Terazono et al. 2003). In restricted feeding, both adrenergic stimulation and twicedaily meals exerted a similar entraining effect, suggesting a common pathway. However, feeding every $6 \mathrm{~h}$ failed to entrain, suggesting that the adrenergic response to food restriction is hierarchically dominant (Hara et al. 2001, Stokkan et al. 2001).

In diabetes mellitus, the effects of the ANS on hepatic glucose production are impaired. This has been attributed to a possible lower production of orexin in SCNcontrolled hypothalamic neurons, which usually regulate daily variations in sympathetic and parasympathetic tone. In orexin deficiency, such as seen in narcolepsy with cataplexy (Poli et al. 2009), the metabolic alterations appear to be independent of body mass, and orexin knockout mice show a significantly altered circadian rhythm of insulin sensitivity and glucose production in the liver (Tsuneki et al. 2015).

The dysfunctional ANS circadian rhythm and misalignment of the endogenous cardiac clocks seem to play a role in the development of cardiovascular disease (CVD) (Takeda \& Maemura 2015). The loss of the nighttime fall in blood pressure (non-dipper pattern) is the first sign of CVD in Cushing's syndrome (Isidori et al. $2015 a$ ), and patients with mild autonomous cortisol secretion exhibit increased arterial stiffness and cardiac remodeling (Sbardella et al. 2018).

Even though an exhaustive discussion of ANS involvement in heart rate variation is beyond the scope of this review, its main influence on circadian heart rate regulation seems to be exerted by ion channel transcription modulation (Tong et al. 2013), given the persistence of a robust circadian rhythm in adrenergic blockade models and autonomic denervated heart transplant recipients (Black

Table 1 Commonly prescribed drugs for diabetes, dyslipidemia, hyperuricemia that target circadian genes.

\begin{tabular}{l}
\hline Drugs \\
\hline Dipeptidyl peptidase-4 inhibitors \\
Gliclazide \\
Glimepiride \\
Insulin \\
Metformin \\
Pioglitazone \\
Alirocumab \\
Atorvastatin \\
Ezetimibe \\
Lovastatin, Fluvastatin, Pravastatin, Rosuvastatin, and \\
Simvastatin \\
Fenofibrate \\
Allopurinol and Febuxostat
\end{tabular}

\begin{tabular}{l}
\hline Indication \\
\hline Diabetes mellitus \\
Diabetes mellitus \\
Diabetes mellitus \\
Diabetes mellitus \\
Diabetes mellitus \\
Diabetes mellitus \\
Dyslipidemia \\
Dyslipidemia \\
Dyslipidemia \\
Dyslipidemia
\end{tabular}

Hypertriglyceridemia Hyperuricemia

\begin{tabular}{l}
\hline Circadian gene target \\
\hline$D P P 4$ \\
$A B C C 8$ and VEGFA \\
$K C N / 1$ and $A B C C 8$ \\
IGF1R and INSR \\
PRKAB1, ETFDH and GPD1 \\
PPARG and MAOB \\
PCSK9 \\
HMGCR, DPP4, AHR and NR1I3 \\
SOAT1 \\
HMGCR
\end{tabular}

PPARA, NR1/2 and MMP25 $X D H$ 
et al. 2019). Interestingly, beta-adrenergic knockout mice models show persistent oscillation of clock-related genes, but with alterations of period and amplitude (Barbagallo F \& Isidori AM, unpublished observations). This could possibly lead to inappropriate coupling of oxygen supply and cardiac requirements. Finally, the renin-angiotensinaldosterone pathway is also deeply interconnected with the circadian rhythmicity, intrinsic renal and adrenal clock genes, and the HPA axis (see Box 2).

\section{The immune system and inflammation}

One of the most important functions of the circadian mechanism is to prevent disease caused by exogenous pathogens. It does this by priming immune function during the active phase while promoting tissue repair during resting hours. Infectious challenges produce a different host response depending on the time of exposure. Circadian peaks and troughs in bone marrow release, peripheral migration, and tissue homing have been demonstrated in almost all immune cell populations (Boivin et al. 2003, Silver et al. 2012, Adrover et al. 2019), resulting in oscillating bloodstream concentrations of inflammatory mediators (Liu et al. 2006, Rahman et al. 2015).

Many studies have revealed direct interactions between circadian genes and inflammation (Gibbs et al. 2012), mostly targeting nuclear factor kappa-light-chainenhancer of activated B cells (NF-kB) (Spengler et al. 2012, Curtis et al. 2015). NF-kB is also one of the key targets mediating the effect of glucocorticoids on inflammation, and glucocorticoids are often given to treat inflammation, without regard to any consequent circadian misalignment (Isidori et al. 2020). In fact, circadian rhythm alterations enhance inflammatory response to exogenous pathogens (Castanon-Cervantes et al. 2010), but even in the absence of pathogenic challenge, they seem to promote a shift toward a constitutively pro-inflammatory state (Polidarova et al. 2017). To add more complexity to this scenario, inflammatory cytokines also affect circadian rhythm: for example, interleukin $1 \beta$ and tumor necrosis factor alpha can repress the activity of CLOCK/BMAL (Cavadini et al. 2007). The typical feature of dysregulated and uncontrolled inflammatory response is sepsis, which is also characterized by altered circadian rhythm. While these two aspects seem tightly intertwined, it is not yet clear whether inflammation disrupts circadian rhythms or pre-existing circadian rhythm disruption enhances inflammatory response in critically ill patients. In trauma patients, alterations in cortisol acrophase and circadian rhythm have been associated with the development of sepsis (Coiffard et al. 2019). These findings suggest that the disruption of circadian gene rhythmicity by an external challenge (such as trauma or bacterial infection) increases the susceptibility to sepsis (Coiffard et al. 2019). Interestingly, patients with Cushing's are at an increased risk of sepsis (Hasenmajer et al. 2020). Glucocorticoids also influence all the components of the immune system, including macrophages, neutrophils, eosinophils,

\section{Box 2: Hyperaldosteronism and clock genes}

Circadian rhythm is known to influence blood pressure. The role of clock genes in aldosterone secretion has been recently investigated. First, Cry-null mice, lacking the core-clock components Cry1 and Cry2, were shown to exhibit salt-sensitive hypertension due to autonomous aldosterone production, as a consequence of the massive upregulation in the mice counterpart

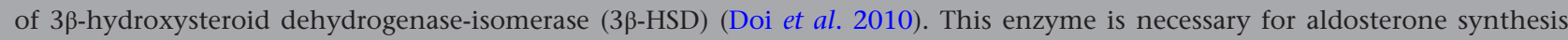
and also plays a key role in the development of primary aldosteronism (PA) (Konosu-Fukaya et al. 2015). PA has two major subtypes, aldosterone-producing adenoma (APA), in which excess aldosterone is secreted by a unilateral adrenal adenoma, and idiopathic hyperaldosteronism (IHA), in which it is secreted due to bilateral adrenal hyperplasia. Doi et al. reported that adrenal

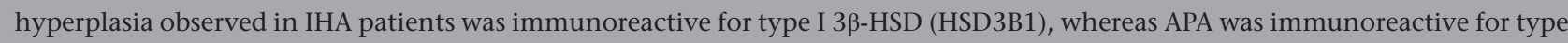
II (HSD3B2), not for HSD3B1. They also reported that HSD3B2 is regulated by ACTH, but HSD3B1 is apparently regulated by other factors, such as clock genes (Doi et al. 2010).

In mice, downregulation of Per1 is associated with lower plasma aldosterone and reduced HSD3B1, reinforcing the idea that Per1 might be modulating aldosterone levels (Richards et al. 2013). Interestingly, ACTH is also reported to stimulate aldosterone secretion, more strongly in APAs, less in IHA (Sonoyama et al. 2014); it also stimulates PER1, indicating a potential role for the intrinsic clock gene/ACTH network in the development of APA (Campino et al. 2011). Angelousi et al. found an increase in PER1, CLOCK, BMAL1, CRY1, REV-ERB, and RORA mRNA expression and protein levels in human APAs compared with the surrounding non-adenomatous tissues, although clock gene expression was not correlated with tumor size, aldosterone level, or plasma renin activity (Angelousi et al. 2020). Treatment of human adrenocortical cells with angiotensin caused a significant upregulation of CRY1 and downregulation of CRY2 (Tetti et al. 2018). 
NK cells, T lymphocytes, and B lymacs
2014 ). In critically ill patients, glucocorticoids are often administered continuously or with multiple daily boluses and at supra-physiological dosages: this could be one of the reasons why data on glucocorticoid in sepsis are still controversial. Given its effects on restoration of the circadian rhythm, melatonin has been proposed as an adjunct therapy in sepsis, but data on its effectiveness are not yet available (Colunga Biancatelli et al. 2020).

Outside critical care, the sustained low-grade chronic inflammatory response observed in various models of circadian dysregulation (Isidori et al. 2018) suggests that inflammation could contribute to the increased risk of metabolic diseases in shift workers. This may significantly increase both the metabolic consequences of dietinduced obesity (Kim et al. 2018) and cardiovascular risk (Schilperoort et al. 2020).

\section{Is the glucocorticoid effector system the watchmaker?}

The system through which glucocorticoids fine-tune the peripheral clocks while synchronizing the metabolic, inflammatory, and brain responses to acute and chronic stress remains largely underexplored (Fig. 1). Since the discovery of peripheral and central clocks and their phase-shifting (Yamazaki et al. 2000), glucocorticoids have been ideal candidates for entraining the periphery with the central pacemaker. Their secretion follows a marked daily rhythm and GR is expressed in almost every peripheral cell except the SCN (Rosenfeld et al. 1988, Balsalobre et al. 2000). It has also been demonstrated that glucocorticoid treatment could phase-shift circadian clocks in peripheral cells (Balsalobre et al. 2000, Cuesta et al. 2015) and that this effect did not occur in tissues lacking functional GR. Furthermore, glucocorticoids directly induced clock gene expression in both mouse (Balsalobre et al. 2000) and human studies (Yurtsever et al. 2016). In fact, glucocorticoid responsive elements have been described in the promoter regions of genes in the PERIOD family (Reddy et al. 2009), but glucocorticoidinduced transcription seems to depend on more complex mechanisms, such as chromatin accessibility (John et al. 2011, Reddy et al. 2012) and other mediators such as the circadian gene Bmal1 (Cheon et al. 2013) and its capacity to rhythmically regulate a network of enhancers (Beytebiere et al. 2019). Interestingly, glucocorticoidinduced phase-shifting did not occur in PER1 knockout models. This suggests that Per plays a major role in mediating the effects of glucocorticoids on other circadian components of the clock mechanism, such as Bmal1, Rev-Erb, and Clock (Koyanagi et al. 2006), even though glucocorticoids can directly repress REV-ERB expression (Murayama et al. 2019) and CLOCK and CRY have been shown to physically interact with the GR, inhibiting its transcriptional activity (Nader et al. 2009, Lamia et al. 2011) (Fig. 3). This last observation brought into question the prominent role of endogenous glucocorticoids in regulating peripheral rhythmicity, invoking a hierarchic role for clock-dependent regulation of GR expression in the tissue, rather than daily fluctuations of the circulating hormones.

In the debate over whether the main timekeeper is cortisol, its receptor, or neither of these, it is worth remembering which mechanisms control GR activity.

The GR is located in the cytosol. The presence of chaperone protein HPS90 is fundamental for maintenance of the high-affinity form, while two other binding proteins, the immunophillins FKBP51 and FKBP52, compete to associate with the HPS90-GR complex and can regulate its translocation to the nucleus following ligand binding (Wochnik et al. 2005).

The imbalance between FKBP51 and FKBP52 can interfere with GR activation, leading to glucocorticoid resistance. GR is both a target and a transcriptional factor of FKBP52 protein, while FKBP51 interferes with GR activity. Enhanced levels of FKBP5 have been described in several diseases characterized by altered glucocorticoid sensitivity, such as Cushing's Syndrome (Resmini et al. 2016).

Several studies have recently highlighted the importance of circadian variations in GR activity over glucocorticoid rhythmicity in mediating immune response. A rhythmic inflammatory response to lipopolysaccharide challenge in airway epithelial cells was maintained in the absence of glucocorticoid rhythmic secretion in experimental models that preserved GR ligand availability (Ince et al. 2019), while it was lost in adrenalectomized mice (Gibbs et al. 2014).

However, the role of the circadian rhythm in modulating glucocorticoid sensitivity in peripheral organs has been best evaluated in 'metabolic' organs (Caratti et al. 2018). Glucocorticoids exert different effects on 'metabolic' tissues such as the liver depending on the timing of administration, while other 'non-metabolic' organs such as the lung did not show any difference in target gene expression at different timepoints. Interestingly, the co-binding of GR with circadian nuclear receptor REV-ERBa is necessary for transcription of target genes 


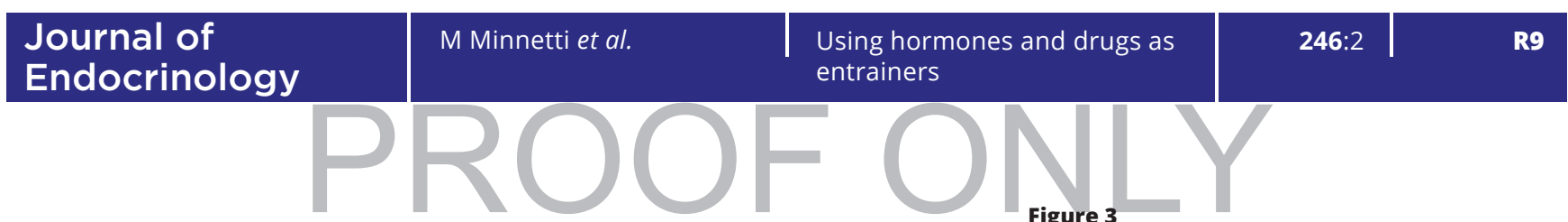

Figure 3

Involvement of the main metabolic drugs and glucocorticoids in the transcriptional feedback loop of the mammalian circadian clock. The CLOCKBMAL1 heterodimer activates transcription of $P E R$, $C R Y, R O R A$, and REV-ERBA through binding to $\mathrm{E}$-box in their promoters. Upon accumulation, PER and CRY dimerize and translocate into the nucleus to repress CLOCK-BMAL1activity and hence their own transcription. RORA activates and REV-ERB represses RORE-mediated transcription. The Glucocorticoid receptor (GR) interacts with CRY and glucocorticoids can directly repress REV-ERBA. ACTH stimulates steroidogenesis (STAR) and PER, that in turn blunts ACTH stimulation of STAR that is also inhibited by Melatonin. Metformin activates hepatic Sirtuin 1 (SIRT1) through AMPK-mediated induction of NAMPT. SIRT1 binds CLOCK-BMAL1 in a circadian manner and promotes the deacetylation and degradation of PER. PPARA ligands, such as fibrates, and PPARG ligands, such as pioglitazone, impair SIRT1; in vitro PPARA and PPARG regulate the expression of BMAL1 and REV-ERBA. Insulin receptor (INSR) activation increases PI3K, leading to activation of mTOR complex (MTORC), essential for PER induction. Atorvastatin is an agonist of aryl hydrocarbon receptor (AHR), which regulates the circadian clock by repressing the CLOCKBMAL1 heterodimer and thereby inhibiting the expression of PER1. Solid/dashed blue lines refer to activation/inhibition of signaling steps, respectively. Solid/dashed black lines refer to activation/inhibition of gene transcription, respectively.

associated with lipid metabolism in the liver, as shown in Rev-Erba-KO mice, which did not present any of the well-known effects of glucocorticoids on lipid metabolism (Caratti et al. 2018). Finally, metabolic sensitivity to glucocorticoid is also modulated by hepatocyte nuclear factors (HNFs), such as HFN6 and HFN4A (Reddy et al. 2007, Zhang et al. 2016, Qu et al. 2018).

Specifically, the synchronizing effect of glucocorticoids is attenuated in liver HFN4A knockout mice (Reddy et al. 2007). In summary, at physiological concentrations of glucocorticoids, $C R Y$-dependent regulation of GR in the liver seems to be the dominant mechanism regulating its time-dependent metabolic sensitivity to glucocorticoids; however, at non-physiological concentrations, such as in adrenal insufficiency or Cushing's syndrome, where $C R Y$ and REV-ERBa are dysregulated (Venneri et al. 2018, Isidori 2019), this might not be the case.

Pharmacological targeting of GR used to be considered the ideal way to potentially uncouple the beneficial and detrimental effects of glucocorticoids. However, although in recent decades several compounds selectively modulating GR or partial GR agonists (Koorneef et al. 2018) have been tested in metabolic and inflammatory diseases
(Lucafo et al. 2020), none of them have made it through to clinical trials. The reason probably lies in the tissuespecific complexity, including clock-dependency (Caratti et al. 2018), of the cofactors modulating glucocorticoid sensitivity. In the context of circadian rhythm alterations, therapies targeting GR could prevent the development of metabolic alterations induced by altered glucocorticoid rhythm and exposure. In the near future, studies on novel GR antagonists (such as relacorilant) with better pharmacokinetics than mifepristone could provide some insight (see subsequent section), but in the current clinical setting GR targeting does not seem to be a feasible way to 'fix the clock'.

\section{Adrenal disorders as models of circadian rhythm disruption}

\section{Hypercortisolism and adrenocortical tumors}

Cushing's Syndrome involves prolonged exposure to endogenous or exogenous glucocorticoids, resulting in a disturbed circadian rhythm (Alexandraki \& Grossman 2010). It is characterized by high morbidity and mortality, 
ascular, infectious, metabolic, and especially due to cardiovascular, infectious, metabolic, and psychiatric conditions (Isidori et al. 2015a,b, Pivonello et al. 2016, Vitale et al. 2017) and largely attributed to the failure of plasma cortisol levels to drop in the late evening and at night. It has been proposed that partial resistance of ACTH-secreting pituitary adenomas to the negative feedback of cortisol alters the secretion of corticotropinreleasing hormone from the hypothalamus, leading to an abnormal circadian rhythm (Moreira et al. 2018). This in turn may contribute to dysregulation of the clock system in peripheral tissues, leading to intermediary metabolic alterations and the clinical features of Cushing's Syndrome. Conversely, PER2-deficient mice show abnormalities in the HPA axis, elevated corticosterone levels, and a disturbed feeding rhythm (Yang et al. 2009). An ex vivo study on normal adrenocortical cells suggests that ACTH stimulates PER1 and BMAL expression and that the interplay between ACTH and clock genes is crucial in regulating the normal steroidogenic response. Interestingly, melatonin seems to directly inhibit ACTHstimulated steroidogenesis (Campino et al. 2011). In mice with a selective knockout of Bmal in the adrenocortical cell, basal steroidogenesis and stress-induced response were maintained (Dumbell et al. 2016), albeit with an exaggerated response, especially in females, and the animals were more vulnerable to light-induced timeshift, suggesting that the adrenal clock machinery acts to buffer steroidogenic responses and stabilize circadian glucocorticoid rhythmicity (Engeland et al. 2018, 2019).

In relation to cortisol-secreting tumors, only two studies have explored clock gene expression in human adrenal tissue (Campino et al. 2011, Angelousi et al. 2020). They found that clock genes were expressed but were dysregulated, with an apparent loss of established feedback loops and a distinct pattern between benign (CSA) and malignant adrenal tumors (ACC). Compared to non-adenomatous adjacent adrenal tissue, PER1, $C R Y 1$, and $R E V-E R B$ were downregulated in CSA, but $R E V$-ERB expression was positively correlated and CLOCK expression negatively correlated with the severity of hypercortisolism. In contrast, CLOCK, CRY1, and PER1 seem to be upregulated and BMAL1 and RORA downregulated in ACC (Angelousi et al. 2020). The studies investigating the link between clock genes and hyperaldosteronism are described in BOX 2.

In summary, hypercortisolism is likely to exert direct and indirect effects on non-endocrine peripheral circadian genes, contributing to worsening of comorbidities. The adrenal clock machinery, which normally buffers response to ACTH and stress, appears dysregulated in adrenal tumors, favoring a higher, arrhythmic corticosteroid output. How and when such alterations can be reversible is the outcome of an ongoing multicentric prospective trial on circadian rhythm in the active and remission phases of Cushing's Syndrome (NCT03343470).

\section{Adrenal insufficiency}

Adrenal insufficiency is characterized by insufficient levels of endogenous glucocorticoids, either due to adrenal dysfunction (the primary form) or to decreased pituitary secretion of ACTH or hypothalamic secretion of corticotropin-releasing hormone (secondary adrenal insufficiency) (Pofi et al. 2018). Patients require lifelong glucocorticoid replacement therapy and several studies have demonstrated their increased mortality and morbidity, mostly due to cardiovascular and infectious diseases and malignancies (Bergthorsdottir et al. 2006, Quinkler et al. 2018). Management of glucocorticoid replacement remains controversial, but most guidelines nowadays advise treating these patients with lower doses of glucocorticoids (usually $<30 \mathrm{mg}$ of hydrocortisone or equivalent glucocorticoid daily dosage) in order to match the serum cortisol levels observed in healthy controls (Bornstein et al. 2016, Isidori et al. 2020). However, several studies failed to demonstrate any clear correlation between glucocorticoid dosage under $35 \mathrm{mg} /$ day and metabolic comorbidities (Bleicken et al. 2010, Castinetti et al. 2015), leading to the hypothesis that the timing of administration is as important as the dose. In fact, glucocorticoid replacement should mimic endogenous secretion, peaking in the early morning and decreasing during the active phase, with a trough at night. Immediaterelease hydrocortisone is therefore administered in two or three doses, with the highest dose in the morning and the lowest at midday and/or in the afternoon, avoiding evening exposure (Bornstein et al. 2016). Despite this, peaks and troughs in serum cortisol levels are unavoidable with immediate-release formulations, leading to possible disruption due to the entraining activity of glucocorticoids on peripheral clocks in multiple organs (Balsalobre et al. 2000).

According to this hypothesis, patients undergoing multiple daily dose replacement therapy for adrenal insufficiency show significant alterations in circadian gene expression compared to healthy controls (Venneri et al. 2018). As observed in other conditions involving a disrupted circadian rhythm, the immune profile of these patients also showed significant alterations, with an increased number of inflammatory monocytes (Isidori 
number of $\mathrm{CD} 16^{+}$natural killer et al. 2018) and reduced number of $\mathrm{CD} 16^{+}$natural killer cells (Bancos et al. 2017, Isidori et al. 2018), along with an increased incidence of infectious diseases (Isidori et al. 2018). This suggests that low-grade inflammation due to circadian disruption could underlie the metabolic comorbidities in adrenal insufficiency, even when patients are treated with adequate tailored daily dosages.

\section{The 'fixing' hypothesis: chrono-pharmacology in glucocorticoid excess and deficiency disorders}

Whether the previously described clock alterations are the cause or the consequence of HPA axis dysregulation remains to be fully elucidated. The evidence that normal surrounding tissue or stimulated tumor cells can modulate clock gene expression suggests that clock dysfunction is a contributing factor but not the main cause of the disease. This raises the hypothesis that an attempt could be made to realign clock-gene expression. However, this intriguing possibility clashes with evidence that, despite the hierarchical structure of the timing system and its continuous resetting by environmental time cues, the intrinsic activity of both the central and peripheral circadian clocks seem to be largely self-sustained. How can the clocks be fixed, considering that, at the molecular level, they share a similar machinery? An insight comes from the theory that tissue-specific chromatin accessibility dictates clock protein binding (John et al. 2011). In other words, the rhythm-specificity of gene expression is conferred by tissue-specific transcription factors - such as HNFs in the liver - that regulate large transcription programs. The second, strongly related concept is that of gating systems, according to which specific, appropriately timed signals can act as gate openers to a different level/phase where the response to identical stimuli is blunted or enhanced. These facilitators or windows could be used to reshape the rhythm and synchronize the otherwise resilient intrinsic clocks. A brief and undoubtedly incomplete list of entrainment mechanisms is provided, starting from basic physiological processes like cell division and moving on to cell nourishment and paracrine-endocrine signaling.

\section{The lesson from the entraining of the clock and cell cycle oscillators}

The coordination of the cell cycle with clock genes is one of the best-studied examples of the entrainment mechanism. The transition between the $\mathrm{G}$ and $\mathrm{S}$ phases of the cell cycle occurs through a gating system that is entrained with clock genes. Using light-responsive zebrafish cell lines, it has been shown that the cell cycle can be synchronized by re-entraining the light:darkness cycles to a different period. The clock uses specific circadian checkpoints to create a window or gate that is either permissive or repressive for cell cycle progression (Laranjeiro et al. 2018).

In this context, glucocorticoids exert a double effect: first, directly on the clock gene mechanism, and second, on the genes that are the targets of clock genes. For the latter mechanism, glucocorticoids can delay the expression or degradation of important factors through the gating transition. This could explain why the healing process is dramatically hampered in cases of glucocorticoid excess.

However, these studies have also revealed that not everything has a clock. Embryonic stem cells, which can develop into almost any cell type, do not keep time, and many cancer cells do not keep a regular rhythm: a modified proliferation and differentiation pattern is common to both stem and cancerous cells (Tsuchiya et al. 2020).

Glucocorticoids are among the most potent prodifferentiation agents used in vitro cell cultures. The glucocorticoid rhythm can promote acceleration or relaxation by moving to or from the gate-point needed to activate specific cell functions, for example, shifting from proliferation into differentiation status.

The clock genes and cell cycle are synchronized to oscillate in coordination around the $24-\mathrm{h}$ period. By experimentally extending the light:darkness period to longer than $24 \mathrm{~h}$, the amplitude of oscillation is lowered and the expression of several clock genes is flattened downstream. This is precisely what is seen in patients receiving glucocorticoids in a non-physiological rhythm (Venneri et al. 2018) or in patients with Cushing's Syndrome (Isidori 2019). All these observations lead to the hypothesis that medical treatments targeting adrenal disorders could be used to entrain clocks that have become misaligned due to the disorder itself.

\section{Treating Cushing's Syndrome and possible autonomous cortisol secretion}

Medical treatments for Cushing's Syndrome can be classified as pituitary-targeting drugs, steroid synthesis inhibitors, and GR antagonists (Feelders et al. 2019). They are generally used when surgery is not indicated or in cases of persistent or recurrent hypercortisolism. Steroidogenesis inhibitors such as ketoconazole or 
metyrapone effectively lower mean 24-h cortisol
values but appear unable to restore the cortisol rhythm (Terzolo et al. 1988, Ceccato et al. 2018). Conversely, the somatostatin analog pasireotide, alone or in combination therapy with cabergoline or ketoconazole, restored the diurnal cortisol rhythm, albeit, in only half of the patients (van der Pas et al. 2013). The activity, kinetics, and toxicity of the drugs used to treat Cushing's Syndrome have seldom taken into account the implications of their administration time. Most studies investigate the overall $24-\mathrm{h}$ cortisol output rather than time-of-day-glucocorticoid exposure curves, despite discussions of their value (Alexandraki \& Grossman 2011). Taking medications at a specific time (chronopharmacology) could help restore physiological cortisol circadian rhythms, thus improving the metabolic and cardiovascular complications associated with hypercortisolism while lowering side effects and toxicity.

In healthy subjects, the four-hourly administration of eight consecutive doses of metyrapone resulted in a marked suppression of the morning cortisol peak, but afternoon, evening, and nighttime cortisol levels were not significantly different from untreated subjects(Plat et al. 1999). Evening administration of metyrapone seems to restore a normal cortisol rhythm in patients with adrenal incidentalomas and autonomous (mild) cortisol secretion (Debono et al. 2017). Counterintuitively, to date, none of the trials on Cushing's syndrome treatment have included the normalization of evening/ night cortisol levels as a primary or secondary outcome (instead investigating only total 24-h output), even though rhythm alteration is the first hallmark sign of this syndrome.

The MAPEC study showed that taking antihypertensive drugs at bedtime improve the cardiovascular risk of patients with a non-dipping pattern, compared to morning administration (Hermida et al. 2010).

Similarly, women who received morning teriparatide treatment showed a lower bone resorption marker (CTX) level and increased lumbar spine bone mineral density compared to those receiving evening teriparatide (Luchavova et al. 2011). The chrono-pharmacology of metabolically active drugs will be discussed in the next section.

In short, if the medications used to target the complications of Cushing's syndrome - hypertension, osteoporosis, and diabetes - work better when given with a chrono-pharmacological approach, it follows that the drug used to treat Cushing's syndrome itself should also take cortisol rhythm into account.

\section{Treating adrenal insufficiency}

Since the development of modified-release glucocorticoid formulations that better mimic the physiological cortisol daily profile, several studies have described the metabolic advantages of these formulations in treating adrenal insufficiency compared to the multiple daily doses of the conventional regimens. Switching to a once-daily formulation improves BMI and body weight (Johannsson et al. 2012, Quinkler et al. 2015, Isidori et al. 2018), glucose metabolism (Graziadio et al. 2018, Isidori et al. 2018), and quality of life (Johannsson et al. 2012, Isidori et al. 2018). The more physiological cortisol rhythm seems to restore the immune alterations observed in these patients by reducing the number of inflammatory monocytes and increasing CD16 ${ }^{+}$natural killer cells (Isidori et al. 2018), ultimately reverting from a low-grade inflammation profile to levels close to healthy controls. These effects have been correlated to an improved circadian gene expression profile (Venneri et al. 2018). The effects of once-daily glucocorticoid therapy on metabolism could be due to the reduced overall daily exposure (Johannsson et al. 2012), but the link between altered circadian profile and metabolic disruption seems to play a role.

Glucocorticoids are powerful entrainers of peripheral clocks and the immune system is one of the most sensitive to this daily 'reset' (Balsalobre et al. 2000). The implications of circadian rhythm disruption were described in more detail in the previous sections. In the total or relative absence of endogenous glucocorticoid secretion, patients with adrenal insufficiency depend on exogenous administration for all the effects of cortisol, including its leading role in transmitting the daily 'central clock' synchronizing impulse to peripheral tissues. The effect is even greater in Addison disease, where adrenalmedullary control of the ANS is also missing and glucocorticoid exposure is the only control mechanism.

To entrain effectively an autonomous oscillatory population such as the clock gene expression loop in peripheral cells, the designed zeitgeber must have an adequate strength and period (Mavroudis et al. 2012). In adrenal insufficiency, this suggests that the glucocorticoid peaks should be as close as possible to physiological amplitude and have a period close to the autonomous rhythm of peripheral clocks, which complete a loop in approximately $24 \mathrm{~h}$. That being said, it is easy to speculate that the presence of rapid variations in glucocorticoid levels due to multiple daily dose therapies could desynchronize peripheral clocks, especially if they are not synchronized 


\section{政}

with other zeitgebers such as ANS activation, meals, or exogenous stress.

Given that circadian disruption has been observed in metabolic diseases and that this is both characterized and enhanced by concomitant low-grade inflammation in the absence of external challenges, the beneficial effects of changing therapy on glucose metabolism, body weight, and immune function should be at least partly due to a more physiological entraining peak of cortisol serum levels.

\section{Melatonin}

The hormone melatonin is produced by the pineal gland. It is a robust circadian rhythm marker (Hardeland et al. 2011), with production beginning at around 22:00-23:00 $\mathrm{h}$, peaking at 02:00-03:00 $\mathrm{h}$, and reaching its lowest level at 09:00-10:00 h (Gooley et al. 2011). Production is affected by light and to some extent by body position, but not by activity, sleep, meals, stress, or the menstrual cycle (Skene \& Arendt 2006, Marseglia et al. 2013). Thus, melatonin seems to be independent of the traditional pathways involving glucocorticoid action. Exogenous administration of melatonin confirms that non-photic stimuli can affect the body clock (Skene \& Arendt 2006). Melatonin provides clock time and seasonal information in central or peripheral (adrenal) circadian clocks (TorresFarfan et al. 2003, Mendez et al. 2012, Leliavski et al. 2015) and also drives darkness-related behaviors, such as sleep propensity. A multi-synaptic pathway controls nocturnal melatonin secretion from the SCN, the paraventricular nucleus, and the upper thoracic spinal cord, culminating in the release of noradrenaline from sympathetic postsynaptic neurons (superior cervical ganglion), which activates $\beta$-adrenoceptors in pinealocytes (Perreau-Lenz et al. 2003, Ishida et al. 2005, Kim et al. 2015). The synthesis of melatonin (N-acetyl-5-methoxytryptamine) involves serotonin (5-hydroxytriptamine) acetylation by the rate-limiting enzyme arylalkylamine $\mathrm{N}$-acetyltransferase (AANAT) and $\mathrm{N}$-acetylserotonin methylation by acetyl serotonin O-methyltransferase (da Silveira Cruz-Machado et al. 2017). AANAT transcription is regulated by darkness (Torres-Farfan et al. 2003); light at night rapidly inhibits AANAT activity (Lewy et al. 1980).

The adrenal gland expresses melatonin receptor (Torres-Farfan et al. 2003, 2011, Mendez et al. 2012, Leliavski et al. 2015). A high-amplitude melatonin rhythm imposed on newborn lambs resulted in suppression of the adrenal clock genes PER1, PER2, CRY2, and CLOCK (Seron-Ferre et al. 2017), whereas BMAL1 maintained normal clock time-related changes, but with higher values (Torres-Farfan et al. 2011, Seron-Ferre et al. 2017). Interestingly, the previously described induction of PER1 by ACTH stimulation of the human adrenal gland can be inhibited, in vitro, by simultaneous treatment with melatonin. The ACTH induced increase in StAR and $3 \beta$-HSD protein expression, involved in cortisol and aldosterone production seems to be blunted by melatonin, in parallel to what occurs for PER1 suggesting that melatonin can modulate the link between ACTH, clock genes, and adrenal steroidogenesis (Campino et al. 2011) (Figs 1 and 3).

Furthermore, the crosstalk between adrenal and pineal glands under inflammatory conditions indicates that glucocorticoids potentiate nocturnal melatonin synthesis by reducing NFкB activity (da Silveira CruzMachado et al. 2017). Similarly, in stressful conditions, by activating both $\alpha$ and $\beta$ adrenoceptors, glucocorticoids reduce melatonin synthesis (Fernandes et al. 2017) by preventing nuclear translocation of $\mathrm{NF \kappa B}$, which binds to $\kappa \mathrm{B}$ elements in the AANAT promoter (Muxel et al. 2012). Nevertheless, decreased melatonin levels in parallel with slightly increased insulin levels were documented in both T2D rats and T2D patients (Peschke et al. 2015). Finally, a new era of chemoprevention involving the use of melatonin in anticancer therapy is in sight, opening up possible new roles for this neuroendocrine clock mediator (Pinato \& Stebbing 2016).

\section{Metabolically active drugs}

Metabolically active drugs are often prescribed for patients with adrenal disorders. Even though these drugs could target circadian genes (Zhang et al. 2014), the influence of their administration time and their circadian effects have not been extensively studied. One of the most well-known examples is short half-life statins: when taken just before bedtime, they lower cholesterol when the biosynthesis rate is at its highest (Miettinen 1982) (Fig. 3).

The first-line treatment for type 2 diabetes, metformin, modulates molecular clock function in insulin-sensitive tissues in mice (Barnea et al. 2012). Table 1 lists the drugs used to treat diabetes, dyslipidemia, hypertriglyceridemia, and hyperuricemia that target at least one circadian gene, according to the database of circadian genes in eukaryotes (Li et al. 2017) and DrugBank (Knox et al. 2011). For example, metformin targets the circadian gene PRKAB1, encoding for a regulatory subunit of AMPK, a master regulator of energy metabolism. Chronic exposure to glucocorticoids can inhibit AMPK activity, exacerbating 
metabolic impairment (Fig. 3). Metformin counteracts this effect and hence might be beneficial for metabolic complications induced by glucocorticoid excess, especially the accumulation of visceral adiposity (ChristCrain et al. 2008, Seelig et al. 2017), even in non-diabetic patients (Pernicova et al. 2020). Since most of the drugs described in Table 1 are commonly given to patients with glucocorticoid excess or deficiency, clarifying their impact on clock molecular pathways could expand the available options for chrono-pharmacological treatment.

\section{Conclusions}

Glucocorticoids are crucial mediators of the interaction between the central and peripheral clocks. In adrenal disorders, dysregulation of clock synchronization caused by disruption of the cortisol circadian rhythm plays a significant role in the development of end organ complications associated with Cushing's syndrome and adrenal insufficiency. Intriguingly, these two conditions, while seemingly opposite in their clinical presentation, share a common pathophysiological pathway in terms of impaired immune function and increased atherosclerotic risk, two systems that are highly sensitive to clock regulation. For these reasons, greater attention should be paid to the medical treatment used to correct glucocorticoid levels. In both replacement and reduction therapies, all attempts should be made to mimic the daily peaks and troughs of cortisol. This means administering medications at an appropriate time that takes account of their pharmacokinetics, to avoid exposure to glucocorticoids late in the evening and at night. In addition, the prescription of metabolic drugs to control glucocorticoid excess should take into account that tissue sensitivity to glucocorticoids can be different throughout the $24 \mathrm{~h}$, hence preference should be given to agents that are more likely to act in phase with the endogenous clock. Endocrinologists, who have a multidisciplinary overview of homeorhesis (as opposed to homeostasis) and the hormonal rhythms that set the pace of so many biological processes, are perfectly positioned to become the new clock repairers: 'Oh dear! Oh dear! I shall be too late!' is Lewis Carroll's reminder to take part in the Adventures in the Wonderland of chronopharmacology.

\section{Declaration of interest}

A $\mathrm{M}$ I received consultation fees, unconditional grants, and hospitality to conferences from IBSA, Takeda, and IPSEN. The other authors have nothing to disclose.

\section{Funding}

The work was funded by the Ministry of University and Research MIUR PRIN 2017HRTZYA (CHRONO-IMAGE).

\section{Acknowledgement}

Medical writing assistance was provided by Marie-Hélène Hayles during the preparation of the manuscript.

\section{References}

Acosta-Galvan G, Yi CX, Van Der Vliet J, Jhamandas JH, Panula P, Angeles-Castellanos M, Del Carmen Basualdo M, Escobar C \& Buijs RM 2011 Interaction between hypothalamic dorsomedial nucleus and the suprachiasmatic nucleus determines intensity of food anticipatory behavior. PNAS 108 5813-5818. (https://doi. org/10.1073/pnas.1015551108)

Adamovich Y, Ladeuix B, Golik M, Koeners MP \& Asher G 2017 Rhythmic oxygen levels reset circadian clocks through HIF1alpha. Cell Metabolism 25 93-101. (https://doi.org/10.1016/j.cmet.2016.09.014)

Adrover JM, Del Fresno C, Crainiciuc G, Cuartero MI, CasanovaAcebes M, Weiss LA, Huerga-Encabo H, Silvestre-Roig C, Rossaint J, Cossio I, et al. 2019 A neutrophil timer coordinates immune defense and vascular protection. Immunity $50390 . e 10-402 . e 10$,

Alexandraki KI \& Grossman AB 2010 Novel insights in the diagnosis of Cushing's syndrome. Neuroendocrinology 92 (Supplement 1) 35-43. (https://doi.org/10.1159/000314295)

Alexandraki KI \& Grossman AB 2011 Is urinary free cortisol of value in the diagnosis of Cushing's syndrome? Current Opinion in Endocrinology, Diabetes, and Obesity 18 259-263. (https://doi.org/10.1097/ MED.0b013e3283487193)

Angelousi A, Nasiri-Ansari N, Karapanagioti A, Kyriakopoulos G, Aggeli C, Zografos G, Choreftaki T, Parianos C, Kounadi T, Alexandraki K, et al. 2020 Expression of clock-related genes in benign and malignant

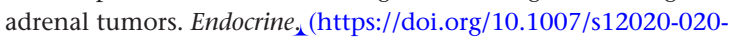
02246-z)

Asher G \& Sassone-Corsi P 2015 Time for food: the intimate interplay between nutrition, metabolism, and the circadian clock. Cell 161 84-92. (https://doi.org/10.1016/j.cell.2015.03.015)

Bailey M \& Silver R 2014 Sex differences in circadian timing systems: implications for disease. Frontiers in Neuroendocrinology 35 111-139. (https://doi.org/10.1016/j.yfrne.2013.11.003)

Balsalobre A, Brown SA, Marcacci L, Tronche F, Kellendonk C, Reichardt HM, Schutz G \& Schibler U 2000 Resetting of circadian time in peripheral tissues by glucocorticoid signaling. Science $\mathbf{2 8 9}$ 2344-2347. (https://doi.org/10.1126/science.289.5488.2344)

Bancos I, Hazeldine J, Chortis V, Hampson P, Taylor AE, Lord JM \& Arlt W 2017 Primary adrenal insufficiency is associated with impaired natural killer cell function: a potential link to increased mortality. European Journal of Endocrinology 176 471-480. (https://doi.org/10.1530/EJE16-0969)

Barnea M, Haviv L, Gutman R, Chapnik N, Madar Z \& Froy O 2012 Metformin affects the circadian clock and metabolic rhythms in a tissue-specific manner. Biochimica et Biophysica Acta 1822 1796-1806. (https://doi.org/10.1016/j.bbadis.2012.08.005)

Baron KG, Reid KJ, Kern AS \& Zee PC 2011 Role of sleep timing in caloric intake and BMI. Obesity 19 1374-1381. (https://doi.org/10.1038/ oby.2011.100)

Bergthorsdottir R, Leonsson-Zachrisson M, Oden A \& Johannsson G 2006 Premature mortality in patients with Addison's disease: a populationbased study. Journal of Clinical Endocrinology and Metabolism 91 4849-4853. (https://doi.org/10.1210/jc.2006-0076) 
Beytebiere JR, Trott AJ, Greenwell BJ, Osborne CA, Vitet H, Spence J, Yoo SH, Chen Z, Takahashi JS, Ghaffari N, et al. 2019 Tissue-specific BMAL1 cistromes reveal that rhythmic transcription is associated with rhythmic enhancer-enhancer interactions. Genes and Development 33 294-309. (https://doi.org/10.1101/gad.322198.118)

Biggi N, Consonni D, Galluzzo V, Sogliani M \& Costa G 2008 Metabolic syndrome in permanent night workers. Chronobiology International 25 443-454. (https://doi.org/10.1080/07420520802114193)

Bingham C, Arbogast B, Guillaume GC, Lee JK \& Halberg F 1982 Inferential statistical methods for estimating and comparing cosinor parameters. Chronobiologia 9 397-439.

Black N, D'souza A, Wang Y, Piggins H, Dobrzynski H, Morris G \& Boyett MR 2019 Circadian rhythm of cardiac electrophysiology, arrhythmogenesis, and the underlying mechanisms. Heart Rhythm 16 298-307. (https://doi.org/10.1016/j.hrthm.2018.08.026)

Bleicken B, Hahner S, Loeffler M, Ventz M, Decker O, Allolio B \& Quinkler M 2010 Influence of hydrocortisone dosage scheme on health-related quality of life in patients with adrenal insufficiency. Clinical Endocrinology 72 297-304. (https://doi.org/10.1111/j.13652265.2009.03596.x)

Boivin DB, James FO, Wu A, Cho-Park PF, Xiong H \& Sun ZS 2003 Circadian clock genes oscillate in human peripheral blood mononuclear cells. Blood 102 4143-4145. (https://doi.org/10.1182/ blood-2003-03-0779)

Bornstein SR, Allolio B, Arlt W, Barthel A, Don-Wauchope A, Hammer GD, Husebye ES, Merke DP, Murad MH, Stratakis CA, et al. 2016 Diagnosis and treatment of primary adrenal insufficiency: an Endocrine Society clinical practice guideline. Journal of Clinical Endocrinology and Metabolism 101 364-389. (https://doi.org/10.1210/ jc.2015-1710)

Brown SA, Kowalska E \& Dallmann R 2012 (Re)inventing the circadian feedback loop. Developmental Cell 22 477-487. (https://doi. org/10.1016/j.devcel.2012.02.007)

Buijink MR, Olde Engberink AHO, Wit CB, Almog A, Meijer JH, Rohling JHT \& Michel S 2020 Aging affects the capacity of photoperiodic adaptation downstream from the central molecular clock. Journal of Biological Rhythms 35 167-179. (https://doi. org/10.1177/0748730419900867)

Buijs RM, La Fleur SE, Wortel J, Van Heyningen C, Zuiddam L, Mettenleiter TC, Kalsbeek A, Nagai K \& Niijima A 2003 The suprachiasmatic nucleus balances sympathetic and parasympathetic output to peripheral organs through separate preautonomic neurons. Journal of Comparative Neurology 464 36-48. (https://doi.org/10.1002/ cne.10765)

Cailotto C, La Fleur SE, Van Heijningen C, Wortel J, Kalsbeek A, Feenstra M, Pévet P \& Buijs RM 2005 The suprachiasmatic nucleus controls the daily variation of plasma glucose via the autonomic output to the liver: are the clock genes involved? European Journal of Neuroscience 22 2531-2540. (https://doi.org/10.1111/j.14609568.2005.04439.x)

Campino C, Valenzuela FJ, Torres-Farfan C, Reynolds HE, AbarzuaCatalan L, Arteaga E, Trucco C, Guzman S, Valenzuela GJ \& SeronFerre M 2011 Melatonin exerts direct inhibitory actions on ACTH responses in the human adrenal gland. Hormone and Metabolic Research 43 337-342. (https://doi.org/10.1055/s-0031-1271693)

Caratti G, Iqbal M, Hunter L, Kim D, Wang P, Vonslow RM, Begley N, Tetley AJ, Woodburn JL, Pariollaud M, et al. 2018 REVERBa couples the circadian clock to hepatic glucocorticoid action. Journal of Clinical Investigation 128 4454-4471. (https://doi.org/10.1172/JCI96138)

Castanon-Cervantes O, Wu M, Ehlen JC, Paul K, Gamble KL, Johnson RL, Besing RC, Menaker M, Gewirtz AT \& Davidson AJ 2010 Dysregulation of inflammatory responses by chronic circadian disruption. Journal of Immunology 185 5796-5805. (https://doi. org/10.4049/jimmunol.1001026)

Castinetti F, Sahnoun M, Albarel F, Morange I, Philippon M, ConteDevolx B \& Brue T 2015 An observational study on adrenal insufficiency in a French tertiary centre: real life versus theory. Annales d'Endocrinologie 76 1-8. (https://doi.org/10.1016/j. ando.2014.11.004)

Cavadini G, Petrzilka S, Kohler P, Jud C, Tobler I, Birchler T \& Fontana A 2007 TNF-alpha suppresses the expression of clock genes by interfering with E-box-mediated transcription. PNAS 104 12843-12848. (https://doi.org/10.1073/pnas.0701466104)

Ceccato F, Zilio M, Barbot M, Albiger N, Antonelli G, Plebani M, Watutantrige-Fernando S, Sabbadin C, Boscaro M \& Scaroni C 2018 Metyrapone treatment in Cushing's syndrome: a real-life study. Endocrine 62 701-711. (https://doi.org/10.1007/s12020-018-1675-4)

Cheon S, Park N, Cho S \& Kim K 2013 Glucocorticoid-mediated Period2 induction delays the phase of circadian rhythm. Nucleic Acids Research 41 6161-6174. (https://doi.org/10.1093/nar/gkt307)

Christ-Crain M, Kola B, Lolli F, Fekete C, Seboek D, Wittmann G, Feltrin D, Igreja SC, Ajodha S, Harvey-White J, et al. 2008 AMPactivated protein kinase mediates glucocorticoid-induced metabolic changes: a novel mechanism in Cushing's syndrome. FASEB Journal 22 1672-1683. (https://doi.org/10.1096/fj.07-094144)

Coiffard B, Diallo AB, Culver A, Mezouar S, Hammad E, Vigne C, Nicolino-Brunet C, Dignat-George F, Baumstarck K, Boucekine M, et al. 2019 Circadian rhythm disruption and sepsis in severe trauma patients. Shock 52 29-36. (https://doi.org/10.1097/ SHK.0000000000001241)

Colles SL, Dixon JB \& O'brien PE 2007 Night eating syndrome and nocturnal snacking: association with obesity, binge eating and psychological distress. International Journal of Obesity 31 1722-1730. (https://doi.org/10.1038/sj.ijo.0803664)

Colunga Biancatelli RML, Berrill M, Mohammed YH \& Marik PE 2020 Melatonin for the treatment of sepsis: the scientific rationale. Journal of Thoracic Disease 12 S54-S65. (https://doi.org/10.21037/ jtd.2019.12.85)

Cornelissen G 2014 Cosinor-based rhythmometry. Theoretical Biology and Medical Modelling 11 16. (https://doi.org/10.1186/1742-4682-1116)

Cuesta M, Cermakian N \& Boivin DB 2015 Glucocorticoids entrain molecular clock components in human peripheral cells. FASEB Journal 29 1360-1370. (https://doi.org/10.1096/fj.14-265686)

Curtis AM, Fagundes CT, Yang G, Palsson-Mcdermott EM, Wochal P, Mcgettrick AF, Foley NH, Early JO, Chen L, Zhang H, et al. 2015 Circadian control of innate immunity in macrophages by miR-155 targeting Bmal1. PNAS 112 7231-7236. (https://doi.org/10.1073/ pnas.1501327112)

Da Silveira Cruz-Machado S, Tamura EK, Carvalho-Sousa CE, Rocha VA, Pinato L, Fernandes PAC \& Markus RP 2017 Daily corticosterone rhythm modulates pineal function through NFkappaB-related gene transcriptional program. Scientific Reports 7 2091. (https://doi. org/10.1038/s41598-017-02286-y)

Damiola F, Le Minh N, Preitner N, Kornmann B, Fleury-Olela F \& Schibler U 2000 Restricted feeding uncouples circadian oscillators in peripheral tissues from the central pacemaker in the suprachiasmatic nucleus. Genes and Development 14 2950-2961. (https://doi. org/10.1101/gad.183500)

Debono M, Harrison RF, Chadarevian R, Gueroult C, Abitbol JL \& Newell-Price J 2017 Resetting the abnormal circadian cortisol rhythm in adrenal incidentaloma patients with mild autonomous cortisol secretion. Journal of Clinical Endocrinology and Metabolism 102 3461-3469. (https://doi.org/10.1210/jc.2017-00823)

Dickmeis T, Lahiri K, Nica G, Vallone D, Santoriello C, Neumann CJ, Hammerschmidt M \& Foulkes NS 2007 Glucocorticoids play a key role in circadian cell cycle rhythms. PLoS Biology 5 e78. (https://doi. org/10.1371/journal.pbio.0050078)

Dickmeis T, Weger BD \& Weger M 2013 The circadian clock and glucocorticoids - interactions across many time scales. Molecular and Cellular Endocrinology 380 2-15. (https://doi.org/10.1016/j. mce.2013.05.012) 
Doi M, Takahashi Y, Komatsu R, Yamazaki F, Yamada H, Haraguchi S, Emoto N, Okuno Y, Tsujimoto G, Kanematsu A, et al. 2010 Saltsensitive hypertension in circadian clock-deficient Cry-null mice involves dysregulated adrenal Hsd3b6. Nature Medicine 16 67-74. (https://doi.org/10.1038/nm.2061)

Dorovini-Zis K \& Zis AP 1991 Innervation of the zona fasciculata of the adult human adrenal cortex: a light and electron microscopic study. Journal of Neural Transmission: General Section 84 75-84. (https://doi. org/10.1007/BF01249111)

Dumbell R, Leliavski A, Matveeva O, Blaum C, Tsang AH \& Oster H 2016 Dissociation of molecular and endocrine circadian rhythms in male mice lacking Bmal1 in the adrenal cortex. Endocrinology 157 4222-4233. (https://doi.org/10.1210/en.2016-1330)

Engeland WC, Massman L, Mishra S, Yoder JM, Leng S, Pignatti E, Piper ME, Carlone DL, Breault DT \& Kofuji P 2018 The adrenal clock prevents aberrant light-induced alterations in circadian glucocorticoid rhythms. Endocrinology 159 3950-3964. (https://doi.org/10.1210/ en.2018-00769)

Engeland WC, Massman L, Miller L, Leng S, Pignatti E, Pantano L, Carlone DL, Kofuji P \& Breault DT 2019 Sex differences in adrenal Bmal1 deletion-induced augmentation of glucocorticoid responses to stress and ACTH in mice. Endocrinology 160 2215-2229. (https://doi. org/10.1210/en.2019-00357)

Feelders RA, Newell-Price J, Pivonello R, Nieman LK, Hofland LJ \& Lacroix A 2019 Advances in the medical treatment of Cushing's syndrome. Lancet: Diabetes and Endocrinology 7 300-312. (https://doi. org/10.1016/S2213-8587(18)30155-4)

Fernandes PA, Tamura EK, D'argenio-Garcia L, Muxel SM, Da Silveira Cruz-Machado S, Marcola M, Carvalho-Sousa CE, Cecon E, Ferreira ZS \& Markus RP 2017 Dual effect of catecholamines and corticosterone crosstalk on pineal gland melatonin synthesis. Neuroendocrinology 104 126-134. (https://doi. org/10.1159/000445189)

Fonken LK, Workman JL, Walton JC, Weil ZM, Morris JS, Haim A \& Nelson RJ 2010 Light at night increases body mass by shifting the time of food intake. PNAS 107 18664-18669. (https://doi. org/10.1073/pnas.1008734107)

Fourier JBJ \& Freeman A 1878 The Analytical Theory of Heat. Cambridge Eng., The University Press.

Fuse Y, Hirao A, Kuroda H, Otsuka M, Tahara Y \& Shibata S 2012 Differential roles of breakfast only (one meal per day) and a bigger breakfast with a small dinner (two meals per day) in mice fed a highfat diet with regard to induced obesity and lipid metabolism. Journal of Circadian Rhythms 10 4. (https://doi.org/10.1186/1740-3391-10-4)

Gibbs JE, Blaikley J, Beesley S, Matthews L, Simpson KD, Boyce SH, Farrow SN, Else KJ, Singh D, Ray DW, et al. 2012 The nuclear receptor REV-ERBalpha mediates circadian regulation of innate immunity through selective regulation of inflammatory cytokines. PNAS 109 582-587. (https://doi.org/10.1073/pnas.1106750109)

Gibbs J, Ince L, Matthews L, Mei J, Bell T, Yang N, Saer B, Begley N, Poolman T, Pariollaud M, et al. 2014 An epithelial circadian clock controls pulmonary inflammation and glucocorticoid action. Nature Medicine 20 919-926. (https://doi.org/10.1038/nm.3599)

Gooley JJ, Chamberlain K, Smith KA, Khalsa SB, Rajaratnam SM, Van Reen E, Zeitzer JM, Czeisler CA \& Lockley SW 2011 Exposure to room light before bedtime suppresses melatonin onset and shortens melatonin duration in humans. Journal of Clinical Endocrinology and Metabolism 96 E463-E472. (https://doi.org/10.1210/jc.2010-2098)

Graziadio C, Hasenmajer V, Venneri MA, Gianfrilli D, Isidori AM \& Sbardella E 2018 Glycometabolic alterations in secondary adrenal insufficiency: does replacement therapy play a role? Frontiers in Endocrinology 9 434. (https://doi.org/10.3389/fendo.2018.00434)

Guan XM, Hess JF, Yu H, Hey PJ \& Van Der Ploeg LH 1997 Differential expression of mRNA for leptin receptor isoforms in the rat brain. Molecular and Cellular Endocrinology 133 1-7. (https://doi.org/10.1016/ s0303-7207(97)00138-x)
Hara R, Wan K, Wakamatsu H, Aida R, Moriya T, Akiyama M \& Shibata S 2001 Restricted feeding entrains liver clock without participation of the suprachiasmatic nucleus. Genes to Cells 6 269-278. (https://doi. org/10.1046/j.1365-2443.2001.00419.x)

Hardeland R, Cardinali DP, Srinivasan V, Spence DW, Brown GM \& Pandi-Perumal SR 2011 Melatonin - a pleiotropic, orchestrating regulator molecule. Progress in Neurobiology 93 350-384. (https://doi. org/10.1016/j.pneurobio.2010.12.004)

Hasenmajer V, Sbardella E, Sciarra F, Minnetti M, Isidori AM \& Venneri MA 2020 The immune system in Cushing's syndrome.

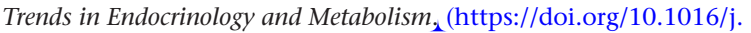
tem.2020.04.004)

Hatori M, Vollmers C, Zarrinpar A, Ditacchio L, Bushong EA, Gill S, Leblanc M, Chaix A, Joens M, Fitzpatrick JA, et al. 2012 Timerestricted feeding without reducing caloric intake prevents metabolic diseases in mice fed a high-fat diet. Cell Metabolism 15 848-860. (https://doi.org/10.1016/j.cmet.2012.04.019)

Hermida RC, Ayala DE, Mojon A \& Fernandez JR 2010 Influence of circadian time of hypertension treatment on cardiovascular risk: results of the MAPEC study. Chronobiology International 27 1629-1651. (https://doi.org/10.3109/07420528.2010.510230)

Hinson JP 1990 Paracrine control of adrenocortical function: a new role for the medulla? Journal of Endocrinology 124 7-9. (https://doi. org/10.1677/joe.0.1240007)

Hirota T, Okano T, Kokame K, Shirotani-Ikejima H, Miyata T \& Fukada Y 2002 Glucose down-regulates Per1 and Per2 mRNA levels and induces circadian gene expression in cultured Rat-1 fibroblasts. Journal of Biological Chemistry 277 44244-44251. (https://doi.org/10.1074/jbc. M206233200)

Hood S \& Amir S 2017 The aging clock: circadian rhythms and later life. Journal of Clinical Investigation 127 437-446. (https://doi.org/10.1172/ JCI90328)

Hsieh SD, Muto T, Murase T, Tsuji H \& Arase Y 2011 Association of short sleep duration with obesity, diabetes, fatty liver and behavioral factors in Japanese men. Internal Medicine 50 2499-2502. (https://doi. org/10.2169/internalmedicine.50.5844)

Ince LM, Zhang Z, Beesley S, Vonslow RM, Saer BR, Matthews LC, Begley N, Gibbs JE, Ray DW \& Loudon ASI 2019 Circadian variation in pulmonary inflammatory responses is independent of rhythmic glucocorticoid signaling in airway epithelial cells. FASEB Journal 33 126-139. (https://doi.org/10.1096/fj.201800026RR)

Isidori AM 2019 Fixing the broken clock in adrenal disorders. Presented at European Conferecen of Endocrinology ECE 2019. Endocrine Abstracts 63. (https://doi.org/10.1530/endoabs.63.S3.2)

Ishida A, Mutoh T, Ueyama T, Bando H, Masubuchi S, Nakahara D, Tsujimoto G \& Okamura H 2005 Light activates the adrenal gland: timing of gene expression and glucocorticoid release. Cell Metabolism 2 297-307. (https://doi.org/10.1016/j.cmet.2005.09.009)

Isidori AM, Graziadio C, Paragliola RM, Cozzolino A, Ambrogio AG, Colao A, Corsello SM, Pivonello R \& Group ABCS 2015a The hypertension of Cushing's syndrome: controversies in the pathophysiology and focus on cardiovascular complications. Journal of Hypertension 33 44-60. (https://doi.org/10.1097/ HJH.0000000000000415)

Isidori AM, Minnetti M, Sbardella E, Graziadio C \& Grossman AB $2015 b$ Mechanisms in endocrinology: the spectrum of haemostatic abnormalities in glucocorticoid excess and defect. European Journal of Endocrinology 173 R101-R113. (https://doi.org/10.1530/EJE-150308)

Isidori AM, Venneri MA, Graziadio C, Simeoli C, Fiore D, Hasenmajer V, Sbardella E, Gianfrilli D, Pozza C, Pasqualetti P, et al. 2018 Effect of once-daily, modified-release hydrocortisone versus standard glucocorticoid therapy on metabolism and innate immunity in patients with adrenal insufficiency (DREAM): a single-blind, randomised controlled trial. Lancet: Diabetes and Endocrinology 6 173-185. (https://doi.org/10.1016/S2213-8587(17)30398-4) 
Isidori AM, Arnaldi G, Boscaro M, Falorni A, Giordano C, Giordano R, Pivonello R, Pozza C, Sbardella E, Simeoli C, et al. 2020 Towards the tailoring of glucocorticoid replacement in adrenal insufficiency: the Italian Society of Endocrinology Expert Opinion. Journal of Endocrinological Investigation 43 683-696. (https://doi.org/10.1007/ s40618-019-01146-y)

Johannsson G, Nilsson AG, Bergthorsdottir R, Burman P, Dahlqvist P, Ekman B, Engstrom BE, Olsson T, Ragnarsson O, Ryberg M, et al. 2012 Improved cortisol exposure-time profile and outcome in patients with adrenal insufficiency: a prospective randomized trial of a novel hydrocortisone dual-release formulation. Journal of Clinical Endocrinology and Metabolism 97 473-481. (https://doi.org/10.1210/ jc.2011-1926)

John S, Sabo PJ, Thurman RE, Sung MH, Biddie SC, Johnson TA, Hager GL \& Stamatoyannopoulos JA 2011 Chromatin accessibility predetermines glucocorticoid receptor binding patterns. Nature Genetics 43 264-268. (https://doi.org/10.1038/ng.759)

Jones PJ, Leitch CA \& Pederson RA 1993 Meal-frequency effects on plasma hormone concentrations and cholesterol synthesis in humans. American Journal of Clinical Nutrition 57 868-874. (https:// doi.org/10.1093/ajcn/57.6.868)

Kahleova H, Lloren JI, Mashchak A, Hill M \& Fraser GE 2017 Meal frequency and timing are associated with changes in body mass index in adventist health study 2. Journal of Nutrition 147 1722-1728. (https://doi.org/10.3945/jn.116.244749)

Kalsbeek A, Bruinstroop E, Yi CX, Klieverik LP, La Fleur SE \& Fliers E 2010 Hypothalamic control of energy metabolism via the autonomic nervous system. Annals of the New York Academy of Sciences 1212 114-129. (https://doi.org/10.1111/j.1749-6632.2010.05800.x)

Kesse WK, Parker TL \& Coupland RE 1988 The innervation of the adrenal gland. I. The source of pre- and postganglionic nerve fibres to the rat adrenal gland. Journal of Anatomy 157 33-41.

Kim TW, Jeong JH \& Hong SC 2015 The impact of sleep and circadian disturbance on hormones and metabolism. International Journal of Endocrinology 2015 591729. (https://doi.org/10.1155/2015/591729)

Kim SM, Neuendorff N, Alaniz RC, Sun Y, Chapkin RS \& Earnest DJ 2018 Shift work cycle-induced alterations of circadian rhythms potentiate the effects of high-fat diet on inflammation and metabolism. FASEB Journal 32 3085-3095. (https://doi.org/10.1096/ fj.201700784R)

Knox C, Law V, Jewison T, Liu P, Ly S, Frolkis A, Pon A, Banco K, Mak C, Neveu V, et al. 2011 DrugBank 3.0: a comprehensive resource for 'omics' research on drugs. Nucleic Acids Research 39 D1035-D1041. (https://doi.org/10.1093/nar/gkq1126)

Konosu-Fukaya S, Nakamura Y, Satoh F, Felizola SJ, Maekawa T, Ono Y, Morimoto R, Ise K, Takeda K, Katsu K, et al. 2015 3betaHydroxysteroid dehydrogenase isoforms in human aldosteroneproducing adenoma. Molecular and Cellular Endocrinology $\mathbf{4 0 8}$ 205-212. (https://doi.org/10.1016/j.mce.2014.10.008)

Koorneef LL, van den Heuvel JK, Kroon J, Boon MR, 't Hoen PAC, Hettne KM, van de Velde NM, Kolenbrander KB, Streefland TCM, Mol IM, et al. 2018 Selective glucocorticoid receptor modulation prevents and reverses nonalcoholic fatty liver disease in male mice. Endocrinology 159 3925-3936. (https://doi.org/10.1210/en.201800671)

Kovacs WJ 2014 To B or not to B? Glucocorticoid impact on B lymphocyte fate and function. Endocrinology 155 339-342. (https:// doi.org/10.1210/en.2013-2085)

Koyanagi S, Okazawa S, Kuramoto Y, Ushijima K, Shimeno H, Soeda S, Okamura H \& Ohdo S 2006 Chronic treatment with prednisolone represses the circadian oscillation of clock gene expression in mouse peripheral tissues. Molecular Endocrinology 20 573-583. (https://doi. org/10.1210/me.2005-0165)

Laermans J, Broers C, Beckers K, Vancleef L, Steensels S, Thijs T, Tack J \& Depoortere I 2014 Shifting the circadian rhythm of feeding in mice induces gastrointestinal, metabolic and immune alterations which are influenced by ghrelin and the core clock gene Bmal1. PLOS ONE 9 e110176. (https://doi.org/10.1371/journal.pone.0110176)

Lamia KA, Sachdeva UM, Ditacchio L, Williams EC, Alvarez JG, Egan DF, Vasquez DS, Juguilon H, Panda S, Shaw RJ, et al. 2009 AMPK regulates the circadian clock by cryptochrome phosphorylation and degradation. Science 326 437-440. (https://doi.org/10.1126/ science.1172156)

Lamia KA, Papp SJ, Yu RT, Barish GD, Uhlenhaut NH, Jonker JW, Downes M \& Evans RM 2011 Cryptochromes mediate rhythmic repression of the glucocorticoid receptor. Nature $\mathbf{4 8 0} 552-556$. (https://doi.org/10.1038/nature10700)

Laranjeiro R, Tamai TK, Letton W, Hamilton N \& Whitmore D 2018 Circadian clock synchronization of the cell cycle in zebrafish occurs through a gating mechanism rather than a period-phase locking process. Journal of Biological Rhythms 33 137-150.

Leliavski A, Dumbell R, Ott V \& Oster H 2015 Adrenal clocks and the role of adrenal hormones in the regulation of circadian physiology. Journal of Biological Rhythms 30 20-34. (https://doi. org/10.1177/0748730414553971)

Lesauter J, Hoque N, Weintraub M, Pfaff DW \& Silver R 2009 Stomach ghrelin-secreting cells as food-entrainable circadian clocks. PNAS 106 13582-13587. (https://doi.org/10.1073/pnas.0906426106)

Lewy AJ, Wehr TA, Goodwin FK, Newsome DA \& Markey SP 1980 Light suppresses melatonin secretion in humans. Science 210 1267-1269. (https://doi.org/10.1126/science.7434030)

Li S, Shui K, Zhang Y, Lv Y, Deng W, Ullah S, Zhang L \& Xue Y 2017 CGDB: a database of circadian genes in eukaryotes. Nucleic Acids Research 45 D397-D403. (https://doi.org/10.1093/nar/gkw1028)

Liu J, Mankani G, Shi X, Meyer M, Cunningham-Runddles S, Ma X \& Sun ZS 2006 The circadian clock Period 2 gene regulates gamma interferon production of NK cells in host response to lipopolysaccharide-induced endotoxic shock. Infection and Immunity 74 4750-4756. (https://doi.org/10.1128/IAI.00287-06)

Lucafo M, Franzin M, Decorti G \& Stocco G 2020 A patent review of anticancer glucocorticoid receptor modulators (2014-present). Expert Opinion on Therapeutic Patents 30 313-324. (https://doi.org/10.1080/1 3543776.2020.1740206)

Luchavova M, Zikan V, Michalska D, Raska Jr I, Kubena AA \& Stepan JJ 2011 The effect of timing of teriparatide treatment on the circadian rhythm of bone turnover in postmenopausal osteoporosis. European Journal of Endocrinology 164 643-648. (https://doi.org/10.1530/EJE10-1108)

Marseglia L, Aversa S, Barberi I, Salpietro CD, Cusumano E, Speciale A, Saija A, Romeo C, Trimarchi G, Reiter RJ, et al. 2013 High endogenous melatonin levels in critically ill children: a pilot study. Journal of Pediatrics 162 357-360. (https://doi.org/10.1016/j.jpeds.2012.07.019)

Mavroudis PD, Scheff JD, Calvano SE, Lowry SF \& Androulakis IP 2012 Entrainment of peripheral clock genes by cortisol. Physiological Genomics 44 607-621. (https://doi.org/10.1152/ physiolgenomics.00001.2012)

Mendez N, Abarzua-Catalan L, Vilches N, Galdames HA, Spichiger C, Richter HG, Valenzuela GJ, Seron-Ferre M \& Torres-Farfan C 2012 Timed maternal melatonin treatment reverses circadian disruption of the fetal adrenal clock imposed by exposure to constant light. PLoS ONE 7 e42713. (https://doi.org/10.1371/journal.pone.0042713)

Mieda M, Williams SC, Sinton CM, Richardson JA, Sakurai T \& Yanagisawa M 2004 Orexin neurons function in an efferent pathway of a food-entrainable circadian oscillator in eliciting food-anticipatory activity and wakefulness. Journal of Neuroscience 24 10493-10501. (https://doi.org/10.1523/JNEUROSCI.3171-04.2004)

Miettinen TA 1982 Diurnal variation of cholesterol precursors squalene and methyl sterols in human plasma lipoproteins. Journal of Lipid Research 23 466-473.

Moreira AC, Antonini SR \& De Castro M 2018 MECHANISMS IN ENDOCRINOLOGY: A sense of time of the glucocorticoid circadian clock: from the ontogeny to the diagnosis of Cushing's syndrome. 
European Journal of Endocrinology 179 R1-R18. (https://doi. org/10.1530/EJE-18-0102)

Murayama Y, Yahagi N, Takeuchi Y, Aita Y, Mehrazad Saber Z, Wada N, Li E, Piao X, Sawada Y, Shikama A, et al. 2019 Glucocorticoid receptor suppresses gene expression of Rev-erbalpha (Nr1d1) through interaction with the CLOCK complex. FEBS Letters 593 423-432. (https://doi.org/10.1002/1873-3468.13328)

Muxel SM, Pires-Lapa MA, Monteiro AW, Cecon E, Tamura EK, FloeterWinter LM \& Markus RP 2012 NF-kB drives the synthesis of melatonin in RAW 264.7 macrophages by inducing the transcription of the arylalkylamine-N-acetyltransferase (AA-NAT) gene. PLoS ONE 7 e52010. (https://doi.org/10.1371/journal.pone.0052010)

Nader N, Chrousos GP \& Kino T 2009 Circadian rhythm transcription factor CLOCK regulates the transcriptional activity of the glucocorticoid receptor by acetylating its hinge region lysine cluster: potential physiological implications. FASEB Journal 23 1572-1583. (https://doi.org/10.1096/fj.08-117697)

Nader N, Chrousos GP \& Kino T 2010 Interactions of the circadian CLOCK system and the HPA axis. Trends in Endocrinology and Metabolism 21 277-286. (https://doi.org/10.1016/j.tem.2009.12.011)

Oike H, Oishi K \& Kobori M 2014 Nutrients, clock genes, and chrononutrition. Current Nutrition Reports 3 204-212. (https://doi. org/10.1007/s13668-014-0082-6)

Ottenweller JE \& Meier AH 1982 Adrenal innervation may be an extrapituitary mechanism able to regulate adrenocortical rhythmicity in rats. Endocrinology 111 1334-1338. (https://doi.org/10.1210/endo111-4-1334)

Partch CL, Green CB \& Takahashi JS 2014 Molecular architecture of the mammalian circadian clock. Trends in Cell Biology 24 90-99. (https:// doi.org/10.1016/j.tcb.2013.07.002)

Pavlovski I, Evans JA \& Mistlberger RE 2018 Feeding time entrains the olfactory bulb circadian clock in anosmic PER2::LUC mice. Neuroscience 393 175-184. (https://doi.org/10.1016/j.neuroscience.2018.10.009)

Pernicova I, Kelly S, Ajodha S, Sahdev A, Bestwick JP, Gabrovska P, Akanle O, Ajjan R, Kola B, Stadler M, et al. 2020 Metformin to reduce metabolic complications and inflammation in patients on systemic glucocorticoid therapy: a randomised, double-blind, placebo-controlled, proof-of-concept, phase 2 trial. Lancet: Diabetes and Endocrinology 8 278-291. (https://doi.org/10.1016/S22138587(20)30021-8)

Perreau-Lenz S, Kalsbeek A, Garidou ML, Wortel J, Van Der Vliet J, Van Heijningen C, Simonneaux V, Pevet P \& Buijs RM 2003 Suprachiasmatic control of melatonin synthesis in rats: inhibitory and stimulatory mechanisms. European Journal of Neuroscience $\mathbf{1 7}$ 221-228. (https://doi.org/10.1046/j.1460-9568.2003.02442.x)

Peschke E, Stumpf I, Bazwinsky I, Litvak L, Dralle H \& Muhlbauer E 2007 Melatonin and type 2 diabetes - a possible link? Journal of Pineal Research 42 350-358. (https://doi.org/10.1111/j.1600079X.2007.00426.x)

Peschke E, Bahr I \& Muhlbauer E 2015 Experimental and clinical aspects of melatonin and clock genes in diabetes. Journal of Pineal Research 59 1-23. (https://doi.org/10.1111/jpi.12240)

Pinato DJ \& Stebbing J 2016 Melatonin: resetting the clock of cancer progression? Lancet: Oncology 17 23-24. (https://doi.org/10.1016/ S1470-2045(15)00571-9)

Pivonello R, Isidori AM, De Martino MC, Newell-Price J, Biller BM \& Colao A 2016 Complications of Cushing's syndrome: state of the art. Lancet: Diabetes and Endocrinology 4 611-629. (https://doi. org/10.1016/S2213-8587(16)00086-3)

Plat L, Leproult R, L'hermite-Baleriaux M, Fery F, Mockel J, Polonsky KS \& Van Cauter E 1999 Metabolic effects of short-term elevations of plasma cortisol are more pronounced in the evening than in the morning. Journal of Clinical Endocrinology and Metabolism $\mathbf{8 4}$ 3082-3092. (https://doi.org/10.1210/jcem.84.9.5978)

Pofi R, Feliciano C, Sbardella E, Argese N, Woods CP, Grossman AB, Jafar-Mohammadi B, Gleeson H, Lenzi A, Isidori AM, et al. 2018
The short Synacthen (corticotropin) test can be used to predict recovery of hypothalamo-pituitary-adrenal axis function. Journal of Clinical Endocrinology and Metabolism 103 3050-3059. (https://doi. org/10.1210/jc.2018-00529)

Poli F, Plazzi G, Di Dalmazi G, Ribichini D, Vicennati V, Pizza F, Mignot E, Montagna P, Pasquali R \& Pagotto U 2009 Body mass indexindependent metabolic alterations in narcolepsy with cataplexy. Sleep 32 1491-1497. (https://doi.org/10.1093/sleep/32.11.1491)

Polidarova L, Houdek P, Sladek M, Novosadova Z, Pacha J \& Sumova A 2017 Mechanisms of hormonal regulation of the peripheral circadian clock in the colon. Chronobiology International 34 1-16. (https://doi. org/10.1080/07420528.2016.1231198)

Qu M, Duffy T, Hirota T \& Kay SA 2018 Nuclear receptor HNF4A transrepresses CLOCK:BMAL1 and modulates tissue-specific circadian networks. PNAS 115 E12305-E12312. (https://doi.org/10.1073/ pnas.1816411115)

Quinkler M, Miodini Nilsen R, Zopf K, Ventz M \& Oksnes M 2015 Modified-release hydrocortisone decreases BMI and HbA1c in patients with primary and secondary adrenal insufficiency. European Journal of Endocrinology 172 619-626. (https://doi.org/10.1530/EJE-14-1114)

Quinkler M, Ekman B, Zhang P, Isidori AM, Murray RD \& Investigators E-A 2018 Mortality data from the European Adrenal Insufficiency Registry-patient characterization and associations. Clinical Endocrinology 89 30-35. (https://doi.org/10.1111/cen.13609)

Rahman SA, Castanon-Cervantes O, Scheer FA, Shea SA, Czeisler CA, Davidson AJ \& Lockley SW 2015 Endogenous circadian regulation of pro-inflammatory cytokines and chemokines in the presence of bacterial lipopolysaccharide in humans. Brain, Behavior, and Immunity 47 4-13. (https://doi.org/10.1016/j.bbi.2014.11.003)

Reddy AB, Maywood ES, Karp NA, King VM, Inoue Y, Gonzalez FJ, Lilley KS, Kyriacou CP \& Hastings MH 2007 Glucocorticoid signaling synchronizes the liver circadian transcriptome. Hepatology $\mathbf{4 5}$ 1478-1488. (https://doi.org/10.1002/hep.21571)

Reddy TE, Pauli F, Sprouse RO, Neff NF, Newberry KM, Garabedian MJ \& Myers RM 2009 Genomic determination of the glucocorticoid response reveals unexpected mechanisms of gene regulation. Genome Research 19 2163-2171. (https://doi.org/10.1101/gr.097022.109)

Reddy TE, Gertz J, Crawford GE, Garabedian MJ \& Myers RM 2012 The hypersensitive glucocorticoid response specifically regulates period 1 and expression of circadian genes. Molecular and Cellular Biology 32 3756-3767. (https://doi.org/10.1128/МСB.00062-12)

Refinetti R, Lissen GC \& Halberg F 2007 Procedures for numerical analysis of circadian rhythms. Biological Rhythm Research 38 275-325. (https:// doi.org/10.1080/09291010600903692)

Resmini E, Santos A, Aulinas A, Webb SM, Vives-Gilabert Y, Cox O, Wand G \& Lee RS 2016 Reduced DNA methylation of FKBP5 in Cushing's syndrome. Endocrine 54 768-777. (https://doi.org/10.1007/ s12020-016-1083-6)

Richards J, Cheng KY, All S, Skopis G, Jeffers L, Lynch IJ, Wingo CS \& Gumz ML 2013 A role for the circadian clock protein Per1 in the regulation of aldosterone levels and renal $\mathrm{Na}+$ retention. American Journal of Physiology: Renal Physiology 305 F1697-F1704. (https://doi. org/10.1152/ajprenal.00472.2013)

Rosenfeld P, Van Eekelen JA, Levine S \& De Kloet ER 1988 Ontogeny of the type 2 glucocorticoid receptor in discrete rat brain regions: an immunocytochemical study. Brain Research 470 119-127. (https://doi. org/10.1016/0165-3806(88)90207-6)

Sbardella E, Minnetti M, D'aluisio D, Rizza L, Di Giorgio MR, Vinci F, Pofi R, Giannetta E, Venneri MA, Vestri A, et al. 2018 Cardiovascular features of possible autonomous cortisol secretion in patients with adrenal incidentalomas. European Journal of Endocrinology $\mathbf{1 7 8}$ 501-511. (https://doi.org/10.1530/EJE-17-0986)

Schilperoort M, Van Den Berg R, Bosmans LA, Van Os BW, Dolle MET, Smits NAM, Guichelaar T, Van Baarle D, Koemans L, Berbee JFP, et al. 2020 Disruption of circadian rhythm by alternating light-dark cycles aggravates atherosclerosis development in $\mathrm{APOE}^{\star} 3$-Leiden.CETP https://joe.bioscientifica.com https://doi.org/10.1530/JOE-20-0066
(C) 2020 Society for Endocrinology Published by Bioscientifica Ltd.
Printed in Great Britain 

mice. Journal of Pineal Research 68 e12614. (https://doi.org/10.1111/
jpi.12614)

Seelig E, Meyer S, Timper K, Nigro N, Bally M, Pernicova I, Schuetz P, Muller B, Korbonits M \& Christ-Crain M 2017 Metformin prevents metabolic side effects during systemic glucocorticoid treatment. European Journal of Endocrinology 176 349-358. (https://doi. org/10.1530/EJE-16-0653)

Seron-Ferre M, Torres-Farfan C, Valenzuela FJ, Castillo-Galan S, Rojas A, Mendez N, Reynolds H, Valenzuela GJ \& Llanos AJ 2017 Deciphering the function of the blunt circadian rhythm of melatonin in the newborn lamb: impact on adrenal and heart. Endocrinology $\mathbf{1 5 8}$ 2895-2905. (https://doi.org/10.1210/en.2017-00254)

Sherman H, Genzer Y, Cohen R, Chapnik N, Madar Z \& Froy O 2012 Timed high-fat diet resets circadian metabolism and prevents obesity. FASEB Journal 26 3493-3502. (https://doi.org/10.1096/fj.12208868)

Silver AC, Arjona A, Walker WE \& Fikrig E 2012 The circadian clock controls toll-like receptor 9-mediated innate and adaptive immunity. Immunity 36 251-261. (https://doi.org/10.1016/j. immuni.2011.12.017)

Skene DJ \& Arendt J 2006 Human circadian rhythms: physiological and therapeutic relevance of light and melatonin. Annals of Clinical Biochemistry 43 344-353. (https://doi. org/10.1258/000456306778520142)

Sonoyama T, Sone M, Tamura N, Honda K, Taura D, Kojima K, Fukuda Y, Kanamoto N, Miura M, Yasoda A, et al. 2014 Role of endogenous ACTH on circadian aldosterone rhythm in patients with primary aldosteronism. Endocrine Connections 3 173-179. (https://doi. org/10.1530/EC-14-0086)

Spengler ML, Kuropatwinski KK, Comas M, Gasparian AV, Fedtsova N, Gleiberman AS, Gitlin Ii, Artemicheva NM, Deluca KA, et al. 2012 Core circadian protein CLOCK is a positive regulator of NF-kappaBmediated transcription. PNAS 109 E2457-E2465.

Stagl M, Bozsik M, Karow C, Wertz D, Kloehn I, Pillai S, Gasser PJ, Gilmartin MR \& Evans JA 2018 Chronic stress alters adrenal clock function in a sexually dimorphic manner. Journal of Molecular Endocrinology 60 55-69. (https://doi.org/10.1530/JME-17-0146)

Stenvers DJ, Scheer FAJL, Schrauwen P, La Fleur SE \& Kalsbeek A 2019 Circadian clocks and insulin resistance. Nature Reviews: Endocrinology 15 75-89. (https://doi.org/10.1038/s41574-018-0122-1)

Stokkan KA, Yamazaki S, Tei H, Sakaki Y \& Menaker M 2001 Entrainment of the circadian clock in the liver by feeding. Science 291 490-493. (https://doi.org/10.1126/science.291.5503.490)

Takeda N \& Maemura K 2015 The role of clock genes and circadian rhythm in the development of cardiovascular diseases. Cellular and Molecular Life Sciences 72 3225-3234. (https://doi.org/10.1007/ s00018-015-1923-1)

Terazono H, Mutoh T, Yamaguchi S, Kobayashi M, Akiyama M, Udo R, Ohdo S, Okamura H \& Shibata S 2003 Adrenergic regulation of clock gene expression in mouse liver. PNAS 100 6795-6800. (https://doi. org/10.1073/pnas.0936797100)

Terzolo M, Panarelli M, Piovesan A, Torta M, Paccotti P \& Angeli A 1988 Ketoconazole treatment in Cushing's disease. Effect on the circadian profile of plasma ACTH and cortisol. Journal of Endocrinological Investigation 11 717-721. (https://doi.org/10.1007/BF03350926)

Tetti M, Castellano I, Venziano F, Magnino C, Veglio F, Mulatero P \& Monticone S 2018 Role of cryptochrome-1 and cryptochrome-2 in aldosterone-producing adenomas and adrenocortical cells. International Journal of Molecular Sciences 19 E1675. (https://doi. org/10.3390/ijms19061675)

Tong M, Watanabe E, Yamamoto N, Nagahata-Ishiguro M, Maemura K, Takeda N, Nagai R \& Ozaki Y 2013 Circadian expressions of cardiac ion channel genes in mouse might be associated with the central clock in the SCN but not the peripheral clock in the heart. Biological Rhythm Research 44 519-530. (https://doi.org/10.1080/09291016.201 2.704801)
Torres-Farfan C, Richter HG, Rojas-Garcia P, Vergara M, Forcelledo ML, Valladares LE, Torrealba F, Valenzuela GJ \& Seron-Ferre M 2003 mt1 melatonin receptor in the primate adrenal gland: inhibition of adrenocorticotropin-stimulated cortisol production by melatonin. Journal of Clinical Endocrinology and Metabolism 88 450-458. (https:// doi.org/10.1210/jc.2002-021048)

Torres-Farfan C, Mendez N, Abarzua-Catalan L, Vilches N, Valenzuela GJ $\&$ Seron-Ferre M 2011 A circadian clock entrained by melatonin is ticking in the rat fetal adrenal. Endocrinology 152 1891-1900. (https:// doi.org/10.1210/en.2010-1260)

Tsuchiya Y, Umemura Y \& Yagita K 2020 Circadian clock and cancer: from a viewpoint of cellular differentiation. International Journal of Urology. (https://doi.org/10.1111/iju.14231)

Tsuneki H, Tokai E, Nakamura Y, Takahashi K, Fujita M, Asaoka T, Kon K, Anzawa Y, Wada T, Takasaki I, et al. 2015 Hypothalamic orexin prevents hepatic insulin resistance via daily bidirectional regulation of autonomic nervous system in mice. Diabetes 64 459-470. (https:// doi.org/10.2337/db14-0695)

Turek FW, Joshu C, Kohsaka A, Lin E, Ivanova G, Mcdearmon E, Laposky A, Losee-Olson S, Easton A, Jensen DR, et al. 2005 Obesity and metabolic syndrome in circadian Clock mutant mice. Science $\mathbf{3 0 8}$ 1043-1045. (https://doi.org/10.1126/science.1108750)

Ulrich-Lai YM, Arnhold MM \& Engeland WC 2006 Adrenal splanchnic innervation contributes to the diurnal rhythm of plasma corticosterone in rats by modulating adrenal sensitivity to ACTH. American Journal of Physiology: Regulatory, Integrative and Comparative Physiology 290 R1128-R1135. (https://doi.org/10.1152/ ajpregu.00042.2003)

Van Der Pas R, De Bruin C, Pereira AM, Romijn JA, Netea-Maier RT, Hermus AR, Zelissen PM, De Jong FH, Van Der Lely AJ, De Herder WW, et al. 2013 Cortisol diurnal rhythm and quality of life after successful medical treatment of Cushing's disease. Pituitary 16 536-544. (https://doi.org/10.1007/s11102-012-0452-2)

Venneri MA, Hasenmajer V, Fiore D, Sbardella E, Pofi R, Graziadio C, Gianfrilli D, Pivonello C, Negri M, Naro F, et al. 2018 Circadian rhythm of glucocorticoid administration entrains clock genes in immune cells: a DREAM trial ancillary study. Journal of Clinical Endocrinology and Metabolism 103 2998-3009. (https://doi. org/10.1210/jc.2018-00346)

Vitale G, Tortora F, Baldelli R, Cocchiara F, Paragliola RM, Sbardella E, Simeoli C, Caranci F, Pivonello R, Colao A, et al. 2017 Pituitary magnetic resonance imaging in Cushing's disease. Endocrine $\mathbf{5 5}$ 691-696. (https://doi.org/10.1007/s12020-016-1038-y)

Vollmers C, Gill S, Ditacchio L, Pulivarthy SR, Le HD \& Panda S 2009 Time of feeding and the intrinsic circadian clock drive rhythms in hepatic gene expression. PNAS 106 21453-21458. (https://doi. org/10.1073/pnas.0909591106)

Wochnik GM, Ruegg J, Abel GA, Schmidt U, Holsboer F \& Rein T 2005 FK506-binding proteins 51 and 52 differentially regulate dynein interaction and nuclear translocation of the glucocorticoid receptor in mammalian cells. Journal of Biological Chemistry 280 4609-4616. (https://doi.org/10.1074/jbc.M407498200)

Xie Y, Tang Q, Chen G, Xie M, Yu S, Zhao J \& Chen L 2019 New insights into the circadian rhythm and its related diseases. Frontiers in Physiology 10 682. (https://doi.org/10.3389/fphys.2019.00682)

Yamazaki S, Numano R, Abe M, Hida A, Takahashi R, Ueda M, Block GD, Sakaki Y, Menaker M \& Tei H 2000 Resetting central and peripheral circadian oscillators in transgenic rats. Science 288 682-685. (https:// doi.org/10.1126/science.288.5466.682)

Yang S, Liu A, Weidenhammer A, Cooksey RC, Mcclain D, Kim MK, Aguilera G, Abel ED \& Chung JH 2009 The role of mPer2 clock gene in glucocorticoid and feeding rhythms. Endocrinology 150 2153-2160. (https://doi.org/10.1210/en.2008-0705)

Yurtsever T, Schilling TM, Kolsch M, Turner JD, Meyer J, Schachinger H \& Schote AB 2016 The acute and temporary modulation of PERIOD genes by hydrocortisone in healthy subjects. Chronobiology 


\section{Journal of \\ International 33 1222-1234. (https://doi.org/10.1080/07420528.2016 .1211668) \\ Zhang R, Lahens NF, Ballance HI, Hughes ME \& Hogenesch JB 2014 A circadian gene expression atlas in mammals: implications for biology and medicine. PNAS 111 16219-16224. (https://doi.org/10.1073/ \\ Zhang Y, Fang B, Damle M, Guan D, Li Z, Kim YH, Gannon M \& Lazar MA 2016 HNF6 and Rev-erbalpha integrate hepatic lipid metabolism by overlapping and distinct transcriptional mechanisms. Genes and Development 30 1636-1644. (https://doi.org/10.1101/ gad.281972.116)} pnas.1408886111)
Received in final form 22 April 2020

Accepted 7 May 2020

Accepted Manuscript published online 7 May 2020 (c) 2020 Society for Endocrinology Published by Bioscientifica Ltd.
Printed in Great Britain 


\section{Author Queries}

JOB NUMBER: 200066

JOURNAL: JOE

Q1 Please check and approve the title.

Q2 Please check and approve the author list.

Q3 Please check and approve the affiliation details.

Q4 Please check that only approved gene and protein nomenclature is used in your paper (human genes in uppercase italics, human proteins in uppercase roman; mouse/rat genes with initial uppercase italics, mouse/rat proteins all uppercase roman). For more details, see https://joe.bioscientifica.com/page/author/author-guidelines\#genes and correct if necessary.

Q5 Please check and approve the identification of the section level headings.

Q6 AQ: Please check the edit made to the sentence "The suprachiasmatic nucleus ( $\mathrm{SCN}$ ) of the hypothalamus receives..." and amend if necessary.

Q7 AQ: Please check if the sentence "The ACTH induced increase in StAR and 3 $\beta$-HSD protein expression..." reads as intended.

Q8 We have been unable to find the DOI for these references; please provide if possible.

Q9 Please update the volume number and page range for the reference 'Angelousi et al. 2020, Hasenmajer et al. 2020, Tsuchiya et al. 2020'.

Q10 Please provide the page number for the reference'Isisori 2019'. 